\section{Tüzel Müşterilerin Ana Bankalarına Yönelik Sadakat ve Ağızdan Ağıza Pazarlama Davranışını Belirleyen Unsurlar: Ankara Örneklemi}

\section{Berrin Arzu Eren ${ }^{\mathrm{a}}$}

Öz: Bu çalışma tüzel müşterilerin ana bankalarına yönelik sadakatlerini; algılanan hizmet kalitesi, müşteri güveni, müşteri tatmini, kurumsal imaj, algılanan değiştirme maliyetleri ve alternatiflerin cazibesi kapsamında açıklamayı amaçlamaktadır. Çalışmanın diğer bir amacı ise hizmet kalitesi ve müşteri sadakati ile ağızdan ağıza pazarlama arasındaki ilişkiyi ortaya koymaktır. Nicel araştırma kapsamında olan çalışmada anket tekniği ile Ankara'da yerleşik 252 tüzel müşteriden veri toplanmışolup, elde edilen veri yapısal eşitlik modellemesi ile analiz edilmiştir. Çalışmada elde edilen bulgulara göre hizmet kalitesi, müşteri tatmini ve alternatiflerin cazibesi müşteri sadakatini belirleyen unsurlar iken; kurumsal imaj, müşteri güveni ve algılanan değiştirme maliyetleri ile müşteri sadakati arasında bir ilişki bulunmamaktadır. Algılanan değiştirme maliyetleri tek başında müşteri sadakatini etkilemezken, müşteri tatmini ve sadakati arasındaki ilişkiyi güçlendirici bir role sahiptir. Son olarak çalışmada elde edilen diğer bir bulgu ise müşteri sadakati ile ağızdan ağıza pazarlama arasındaki doğrusal ilişkinin varlığıdır.

\section{Factors Determining Loyalty and Word-of-Mouth Marketing Behavior of Corporate Customers Towards Their Main Banks: Ankara Sample}

\begin{abstract}
This study aims to explain the loyalty of corporate customers towards their main banks within the scope of perceived service quality, customer trust, customer satisfaction, corporate image, perceived switching costs, and the attractiveness of alternatives. Another aim of the study is to reveal the relationship between service quality and customer loyalty and word-of-mouth. In the study within the scope of quantitative research, data was collected from 252 corporate customers located in Ankara with the survey technique, and the data obtained were analyzed by structural equation model. According to the findings of the study, while service quality, customer satisfaction, and attractiveness of alternatives determine customer loyalty. However, there is no relationship between corporate image, customer trust, and perceived switching costs and customer loyalty. While perceived switching costs do not affect customer loyalty alone, they have a moderating effect on the relationship between customer satisfaction and loyalty. Finally, another finding obtained in the study is the existence of a linear relationship between customer loyalty and word of mouth.
\end{abstract}

Anahtar Sözcükler:

Alternatiflerin Cazibesi, Değiştirme Maliyetleri, Ağızdan Ağıza Pazarlama, Müşteri Sadakati, Müşteri Tatmini

JEL: G21, M31, M39, 031

$\begin{array}{ll}\text { Geliş } & : \text { 15 Ocak } 2021 \\ \text { Düzeltme } & : 01 \text { Mart } 2021 \\ \text { Kabul } & : 05 \text { Nisan } 2021 \\ & \\ \text { Tür } & \text { : Araştırma }\end{array}$

Keywords: Alternatives Attributes, Switching Costs, Word-of-mouth, Customer Loyalty, Customer Satisfaction

JEL: G21, M31, M39, O31
Received : 15 January 2021 Revised : 01 March 2021 Accepted : 05 April 2021

a Asst.Prof., PhD., Ufuk University, Vocational School, Department of Accounting and Tax Applications, Ankara, Turkiye, berrinarzu.eren@ufuk.edu.tr (ORCID ID: 0000-0003-0839-5302) 


\section{Giriş}

Türkiye'de bankacılık sistemi 54 banka ve 9928 şube ile faaliyet göstermektedir (Türkiye Bankalar Birliği, 2020). Bankacılık sisteminde yer alan bankalar da kendi stratejileri doğrultusunda bireysel ve tüzel müşterilerine hizmet sunmaktadırlar. 2020 yılında Türk bankacılık sisteminde yer alan bireysel ve tüzel müşteri sayısına ulaşılamamakla birlikte kredi hacimlerinin büyüklüğü bireysel ve tüzel müşterilerin bankalarda yarattığı hacim ve karlııı hakkında önemli bir göstergedir. Haziran 2020 Bankacılık Sektörü Temel Göstergeleri Raporu'na göre Türkiye'deki toplam kredi büyüklüğünün \%21'ini (699 milyar TL) bireysel kredi kartları ve tüketici kredileri, \%79'unu (2.559 milyar TL) ise KOBi, ticari ve kurumsal nitelikteki tüzel kişiliklere kullandırılan krediler oluşturmaktadır (Bankacılık Denetleme ve Düzenleme Kurumu, 2020). Bu rakamlar bankaların tüzel müşterilerinin bankalar için ne kadar önemli olduğunun önemli bir kanıtıdır. Bununla birlikte bankaların tüzel müşterilerle yüksek hacimlerle çalışabilmeleri ise ancak bu müşterilerin ana bankaları olduklarında mümkün olmaktadır. Tüzel bir müşterinin ana bankası olmak, o müşterinin toplam kredi riski ya da toplam nakit akışında en büyük paya sahip banka olma anlamını taşımaktadır. Bu noktada bankalar için günümüzde en önemli hedeflerden biri müşterilerin ana bankası olmayı başarmak ve bunu sürdürmektir.

Günümüzde bankacılık sektörü artan fiyat rekabeti, ekonomik daralma, yasal düzenlemeler ve sadık müşteri yaratmanın zorluğu içerisinde müşteri sadakati yaratma konusunda ciddi çaba sarf etmektedir (KPMG, 2021). Dolayısıyla bir müşterinin ana bankası olmak ve bunu sürdürmek ise bankalar için önemli bir gündem maddesidir. Bankacılık sektörüne ilişkin alan yazın incelendiğinde hizmet kalitesi, müşteri tatmini, müşteri güveni, kurumsal imaj, müşteri sadakati ve ağızdan ağıza pazarlama konularında yapılan çalışmaların neredeyse tamamının bireysel hedef pazarda yer alan müşteri deneyimlerine ilişkin sonuçları yansıttığı görülmektedir. Bu bağlamda güncel araştırmaların; bankaların sunduğu hizmetin kalitesi ile bireysel müşterilerin bankaya yönelik güveni (Suariedewi ve Suprapti, 2020; Geebren, Jabbar ve Luo, 2021), müşteri tatmini (Nguyen, Pham, Tran ve Pham, 2020; Haron, Subar ve Ibrahim, 2020; Li, Lu, Hou, Cui ve Darbandi, 2021; Srivastava ve Vishnani, 2021; Omar, Mohsin, Tsimonis, Oozeerally ve Hsu, 2021; Kim, Wang ve Roh, 2021), müşteri sadakati (Omar vd., 2021), kurumsal imaj (Wati, Kusuma ve Widnyana, 2020) ve müşteri sadakati ile güven (Haron vd., 2020; Suariedewi ve Suprapti, 2020; Ghali, 2021), müşteri tatmini (Nguyen vd., 2020; Haron vd., 2020; Raza, Umer, Qureshi ve Dahri, 2020; Ghali, 2021; Omar vd., 2021; Kim vd., 2021) ve değiştirme maliyetleri (Zakiy ve Haryanto, 2020; Nguyen vd., 2020) arasındaki ilişkilere odaklandığı görülmektedir. Ayrıca yine güncel çalışmalarda bankaların hizmet kalitesi ve ağızdan ağıza pazarlama (Mukerjee, 2020; Rajaobelina, Tep, Arcand ve Ricard, 2021) ile müşteri sadakati ve ağızdan ağıza pazarlama (Trabelsi-Zoghlami, Berraies ve Yahia, 2020; Rajaobelina vd., 2021) arasındaki ilişkilerin de ayrı ayrı incelendiği görülmektedir. Bu noktada tüzel müşteri sayısının görece olarak bireysel müşterilere kıyasla daha az sayıda olmasına rağmen bankaya yarattığı hacim ve karlııı̆ın daha yüksek olmasından ötürü (Bankacılık Denetleme ve Düzenleme Kurumu, 2020), bankaların bu müşterilerin ana bankası olma ve bunu sürdürme çabasında hizmet kalitesi, müşteri güveni, müşteri tatmini, müşteri sadakati ve ağızdan ağıza pazarlama davranışı arasındaki ilişkilerin ortaya konması önem kazanmaktadır. Bununla birlikte müşteri kayıplarının engellenmesi ve ana banka olmayı sürdürmek için ayrılma maliyetlerinin özellikle müşteri tatmini ve sadakati arasındaki ilişkideki rolünün belirlenmesi gerekmektedir. İçinde bulunduğumuz süreçte bankaların yaşadığı yoğun rekabet, her bankayı rakibine karşı cazip tekliflerle müşteri kazanımına itmektedir. Bu bağlamda ayrılma engellerinin varlığının alternatiflerin çekiciliği ile müşteri sadakati arasındaki ilişkideki rolünün belirlenmesi de bir diğer önemli konudur. Bu doğrultuda çalışma bankacılık ve pazarlama alan yazınına daha geniş bir bakış açısı ile iki yolla katkıda bulunmayı amaçlamaktadır: (i) Tüzel müşterilerin ana bankalarına yönelik sadakatini belirleyen unsurları ortaya koymak ve bu unsurlarla sadakat arasındaki ilişkiyi alternatiflerin çekiciliği ve değiştirme maliyetlerinin etkisi altında incelemek, (ii) tüzel müşterilerin ana bankalarını çevrelerine tavsiyesini belirlemek amacıyla hizmet kalitesi ve sadakat ile ağızdan ağıza pazarlama davranışı arasındaki ilişkiyi ortaya koymak. 


\section{Kavramsal ve Kuramsal Çerçeve}

\subsection{Algılanan Hizmet Kalitesi}

Algılanan hizmet kalitesi müşterinin hizmetin genel mükemmelliği veya üstünlüğüne ilişkin değerlendirmesi olmakla birlikte (Zeithaml, 1988), tek seferlik deneyimler yerine sıklıkla çoklu deneyimlerle yaratılan algılardan oluşmaktadır (Vandamme ve Leunis, 1993). Müşterinin deneyimlediği hizmete ilişkin kalite değerlendirmesi, müşterinin hizmet performansına ilişkin beklentisi ve gerçekleşen performansa ilişkin algısı arasındaki boşluğa bağlıdır (Parasuraman, Zeithaml ve Berry, 1988). Bu tanım gerçekte hizmet kalitesi ölçüm modellerinden SERVQUAL'in de temelini oluşturmaktadır. SERVQUAL modeli hizmet kalitesini 22 alt madde ve beş boyutta değerlendirmektedir: güvenilirlik, isteklilik, fiziksel özellikler, güven ve empati (Parasuraman vd., 1988). Zaman içerisinde SERVQUAL'in bu beş boyutuna yeterlilik, nezaket, inanılırlık, erişim ve iletişim boyutları da eklenmiştir (Parasuraman, Zeithaml ve Berry, 1994). Bu boyutların tüm hizmet sektörlerinde geçerliliği sorgulanmakla birlikte SERVQUAL halen hizmet kalitesinin ölçümünde en sık kullanılan model olmaya devam etmektedir (Hu, Kandampully ve Juwaheer, 2009). İşletmelerin rekabet avantajı elde etmelerine yönelik tasarlanmış bir unsur olan hizmet kalitesi, günümüzde de faaliyetini ve rekabet gücünü sürdürmek isteyen tüm işletmeler için zorunlu bir gereklilik haline gelmiştir (Hu vd., 2009). Bu noktada hizmet kalitesi işletmelerin rekabet avantajı kazanmak için sahip olması gereken özelliklerin toplamı olarak düşünülmektedir.

Bankacılık sektöründe de gerek bankalar gerekse müşteriler için hizmet kalitesi önemli olmakla birlikte, hizmete ve hizmet sürecine ilişkin uzmanlık derecesindeki bilgi yoksunluğu müşteriyi hizmet kalitesini değerlendirmede zaman zaman yetersiz bırakmaktadır. Tüketiciler teknik uzmanlığa ve edinme maliyetleri hakkında gerçekçi bilgiye sahip olmadıklarından, bankacılık hizmetlerinin büyük bölümünde hizmet yoğun bir şekilde kullanıldıktan sonra bile müşteri kendisine yöneltilen teklifin kalitesini doğru ve verimli bir şekilde değerlendirememektedir (Powpaka, 1996). Oysa hizmet kalitesine ilişkin müşteri değerlendirmeleri, gelecekte o işletme ya da işletmenin ürünlerine yönelik geliştirilen müşteri güveni, müşteri tatmini, müşteri sadakati ve ağızdan ağıza pazarlama gibi tutum ve davranışların şekillenmesinde temel basamaklardan biridir (Cronin ve Taylor, 1992). Banka-müşteri ilişkisinde de hizmet kalitesi, müşteri tatmini, müşteri sadakati, olumlu ağızdan ağıza pazarlama ve şikâyet eğilimlerinin azalmasına olumlu katkı sağlamaktadır (Caruana, 2002).

\subsection{Kurumsal İmaj}

Kurumsal imaj, bireylerin bir organizasyona yönelik inançlarının, tutumlarının ve izlenimlerinin toplamından oluşmaktadır (Barich ve Kotler, 1991). Kurumsal imaj, müşterilerin zihninde kalan genel izlenim olmakla birlikte kendine özgü bilişsel bir yapılandırma olarak tanımlanmaktadır (Gray ve Balmer, 1998). Bir işletmenin sahip olduğu kurumsal imaj özellikle hizmet işletmeleri için başarının önemli göstergelerden biridir. Stratejik öneme sahip olan kurumsal imaj zaman içinde şirketin kimlik algısından etkilenerek oluşturulur (Abratt ve Mofokeng, 2001).

İşletmelerin müşterilerine sunduğu hizmetin kalitesi, işletmenin kurumsal imajını etkilemekle birlikte müşteri tatmini için de önemli bir basamaktır (Wu, Lin ve Hsu, 2011). Bu noktada Grönroos (1983)'a göre hizmet kalitesi kurumsal imajın en önemli belirleyicisidir. İşletmenin kurumsal imajı, müşterilerin işletmenin kendisine ve ondan aldığı hizmetin kalitesine ilişkin genel değerlendirmesini artırmada önemli bir rol oynamaktadır (Wu, 2014). Yapılan araştırmalar algılanan hizmet kalitesinin işletmenin kurumsal imajı üzerinde olumlu etkisi olduğunu göstermektedir (Kandampully ve Suhartanto, 2000; Wu, 2014; Clemes, Shu ve Gan, 2014). Konuya ilişkin bu bulgulardan hareketle aşağıdaki hipotez önerilmektedir:

$\boldsymbol{H}_{1}$ : Tüzel müşterilerin ana bankalarından aldıkları hizmetin kalitesine yönelik algıları ile bankanın kurumsal imajı arasında pozitif ve anlamlı bir ilişki bulunmaktadır. 


\subsection{Müşteri Güveni}

Güven, belirli bir değişim ilişkisinde bir tarafın diğer tarafa sağladığı güvenilirlik seviyesidir (Rotter, 1967). Müşterinin işletmeye ya da ürünlerine olan güvenini belirleyen unsursa, işletmenin müşteri beklentilerini ve kendi taahhütlerini ne ölçüde gerçekleştirdiğidir (Moorman, Zaltman ve Deshpande, 1992). Pazarlama alan yazınında müşteri güveni yetkinlik, dürüstlük ve iyilikseverlik olarak üç boyutta değerlendirilmektedir. Yetkinlik, işletmenin müşterinin ihtiyacı olan şeyi yapma yeterliliği; dürüstlük, işletmenin vaatlerini yerine getirmesi ve güvenilir olması; yardımseverlik ise işletmenin müşterilerin çıkarları doğrultusunda hareket etmesi anlamını taşımaktadır (McKnight, Choudhury ve Kacmar, 2002).

Hizmet kalitesi, özellikle de hizmet çalışanının performansı, müşterinin hizmet sağlayıcıya güven geliştirmesine yardımcı olmaktadır (Odekerken-Schröder, Birgelen, Lemmink, Ruyter ve Wetzels, 2000). Hsieh ve Hiang (2004)'ın araştırması da özellikle banka gibi hizmet işletmelerinde müşterilerin hizmet kalitesine ilişkin olumlu algılarının, müşterilerin bankaya yönelik güven geliştirmesinde etkili olduğunu göstermektedir. Algılanan hizmet kalitesi müşterinin işletmeye ve ürünlerine olan güveni olumlu şekilde etkilemektedir (Donney ve Cannon, 1997). Bu noktada bir işletmenin sunduğu hizmetin kalitesi ne kadar yüksekse, müşterilerin işletmeye ve ürünlerine olan güveninin de o ölçüde yüksek olması beklenmektedir (Cho ve Hu, 2009). Çünkü müşterinin işletmeye ve ürüne yönelik beklentileri karşılanmıştır. İlgili alan yazına dayarak aşağıdaki hipotez önerilmektedir:

$\boldsymbol{H}_{2}$ : Tüzel müşsterilerin ana bankalarından aldıkları hizmetin kalitesine yönelik algıları ile müşterilerin bankaya yönelik güveni arasında pozitif ve anlamlı bir ilişki bulunmaktadır.

\subsection{Müşteri Tatmini}

Müşteri tatmini "müşterinin bekledikleri ile elde ettikleri arasında örtüşme oluşması durumudur" (Odabaşı, 2015: 17). Öznel bir değerlendirmeye dayanan müşteri tatmini bireylerin tüketim ve satın almaya yönelik durumunun olumlu bir duygusal tepki ile sonuçlanmasıdır (Kondou, 1997). Gerçekte müşteri tatmini tekli ya da çoklu hizmet karşılaşmalarında müşterinin satın aldığı hizmete yönelik algılarından oluşmaktadır. Işletmeler için tatmin müşteriler yaratmak sağlayacağı avantajlardan ötürü başarılması gereken bir hedeftir. Finansal hizmet sunan işletmeler için de tatmin müşteriler, işletme ve ürünlerine yönelik olumlu tutum ve davranışlar geliştirilmesinden ötürü önemlidir (Chen, Liu, Sheu ve Yang, 2012).

Hizmet sektöründe müşteriye sunulan hizmetin kalitesi müşterinin hizmete ilişkin tatmine ulaşmasında önemli bir unsurdur (Wannenburg, Drotsky ve Jager, 2009). İşletmelerin sunduğu hizmetlerle yarattığı müşteri tatmini müşterilerin kendilerine sunulan hizmeti nasıl algıladıklarına bağlı olup, algılanan hizmet kalitesi ile müşteri tatmini arasında doğrusal bir ilişki bulunmaktadır (Parasuraman vd., 1988; Zeitham, Bitner ve Gremler, 2009). Deneyimlenen hizmetin kalitesi ne kadar yüksekse, müşteri tatminin de o oranda yüksek olacağı beklenmektedir. Çünkü hizmet kalitesi müşteri tatmininin önemli belirleyicilerindendir (Wong ve Fong, 2010). Hizmet kalitesinin yanı sıra müşteri tatminin oluşturulması için işletmelerin kendilerine ve ürünlerine yönelik müşterilerde güven oluşturması da gerekmektedir. Müşterilerin tatmin noktasına ulaşmasında güven anahtar unsurlardan biridir. Yapılan araştırmalar güven ile müşteri tatmini arasındaki doğrusal ilişkiyi doğrulamaktadır (Ranaweera ve Prabhu, 2003; Aydın ve Özer, 2005; Yap, Ramayah ve Shahidan, 2012). Bu bilgiler ışı̆̆ında aşağıdaki hipotezler önerilmektedir:

$\boldsymbol{H}_{3}$ : Tüzel müşterilerin ana bankalarından aldıkları hizmetin kalitesine yönelik algıları ile müşterilerin hizmete yönelik tatmini arasında pozitif ve anlamlı bir ilişki bulunmaktadır.

$\boldsymbol{H}_{4}$ : Tüzel müşterilerin ana bankalarına yönelik güveni ile ana bankalarından aldıkları hizmete yönelik müşteri tatmini arasında pozitif ve anlamlı bir ilişki bulunmaktadır.

İşletmenin sahip olduğu kurumsal imaj müşterilerin işletmenin ürününe yönelik tatminin belirlenmesinde önemli bir unsurdur (Kandampully ve Suhartanto, 2000; O'Leary ve Deegan, 2005). Bu noktada müşterilerin işletmenin kurumsallığına olan inancı ve kurumsal imajına yönelik güçlü algıları arttıkça hizmete ilişkin tatmini de o oranda artmaktadır (Wu, 2014). Geçmişte yapılan çalışmalar da işletmenin kurumsal imajı ile müşteri tatmini arasındaki ilişkinin varlığına işaret etmektedir (Bloemer ve Ruyter, 1998; 
Ball, Coelho ve Vilares, 2006; Richard ve Zhang, 2012). Bu bağlantılara dayanarak aşağıdaki hipotez önerilmektedir:

$\boldsymbol{H}_{5}$ : Tüzel müşterilerin ana bankalarına ilişkin kurumsal imaj algıları ile ana bankalarından aldıkları hizmete yönelik müşteri tatmini arasında pozitif ve anlamlı bir ilişki bulunmaktadır.

\subsection{Değiştirme Maliyetleri}

Değiştirme maliyetleri müşterilerin bir sağlayıcıdan diğerine geçiş süreciyle ilişkilendirdiği ve sadece ekonomik maliyetlerle sınırlandırılamayan maliyetlerdir (Burnham, Frels ve Mahajan, 2003). Değiştirme maliyetleri finansal maliyetlerin yanı sıra sosyal ve psikolojik çabanın yarattığı maliyetleri de içermektedir. Bu bağlamda değiştirme maliyetleri arama maliyetleri, işlem maliyetleri, öğrenme maliyetleri, sadık müşteri indirimleri, müşteri alışkanlığı yaratmak için katlanılan finansal, duygusal ve bilişsel çabaların toplamından oluşmaktadır (Fornell, 1992). İşletmenin yarattığı değiştirme maliyetleri, müşteri kayıplarının önüne geçmede kullanılan önemli bir strateji aracıdır. Araştırmada algılanan değiştirme maliyetleri, alternatif bir bankaya geçişin yarattığı ilişki sonlandırma maliyetleri olup; zaman, enerji ve ekonomik maliyetler kapsamında değerlendirilmiştir.

Algılanan hizmet kalitesi değiştirme maliyetlerini doğrudan etkileyen bir unsurdur (Aydın ve Özer, 2005). Genel olarak, müşteriler hizmet sağlayıcılarını değiştirmek istediklerinde ilk olarak yeni hizmet sağlayıcının hizmet kalitesini (gerçekleşen ya da umulan) mevcut hizmet sağlayııının gerçekleşen hizmet kalitesi ile kıyaslamaktadırlar. Bu noktada yeni hizmet sağlayıcının hizmet kalitesini mevcut sağlayıcının kalitesinden daha iyi algıladıklarında hizmet aldıkları işletmeyi değiştirmektedirler (Chou ve Lu, 2009). Geçmişte yapılan araştırmalar incelendiğinde hizmet kalitesi ile değiştirme maliyetleri arasında doğrusal bir ilişki olduğu görülmektedir (Chen ve Hitt, 2002; Chang ve Chen, 2008). illgili alan yazına dayanarak aşağıdaki hipotez önerilmektedir:

$\boldsymbol{H}_{6}$ : Tüzel müşterilerin ana bankalarından aldıkları hizmetin kalitesine yönelik algıları ile müşterilerin ana bankaları değiştirme durumunda katlanacakları maliyet algıları arasında pozitif ve anlamlı bir ilişki bulunmaktadır.

\subsection{Alternatiflerin Cazibesi}

Alternatiflerin cazibesi, işletmenin faaliyet gösterdiği pazarda uygun rakip alternatiflerin ne ölçüde mevcut olduğuna ilişkin müşteri algıları olarak tanımlanmaktadır (Jones, Beatty ve Mothersbaugh, 2002). Bansal, Taylor ve James (2005)'e göre ise alternatiflerin cazibesi, tüketicilerin pazarda bulunan rakip ürünleri tüketmeleri durumunda memnuniyet elde etmeye ilişkin değerlendirmeleridir. Tüm işletmeler için faaliyet gösterdikleri pazarda alternatif cazip tekliflerin olmaması müşterilerin devamlılı̆ı için önemlidir (Ping, 1993). Müşterilerin mevcut hizmeti rakip işletmelerden aldığında daha yüksek fayda elde edeceklerine inanması, müşterilerin mevcut hizmet sağlayıcı ile olan ilişkisini gözden geçirmesine sebep olmakta, hatta mevcut ilişkisinin devamlılık olasılığını düşürmektedir (Keaveney, 1995). Bu nedenle işletmelerin mevcut teklif ve hizmetlerini rakiplerden üstün ya da avantajlı konumda tutmaları, müşteri devamlılığı için önemlidir.

İsletmenin sunduğu hizmetin kalitesi gerçekte alternatiflerin cazibesini azaltmakta, hatta alternatiflerin dikkate alınmamasına neden olmaktadır (Edward ve Sahadev, 2011). Bu noktada özellikle de bankacılık gibi hizmet kalitesine ilişkin belirsizliklerin olduğu ve değerlendirmenin profesyonel bakış açısı gerektirdiği sektörlerde, alternatif işletmelerin teklifleri çok cazip olsa da müşterilerden mevcut hizmet sağlayıcıları ile devam etme eğiliminde olmaları beklenmektedir. Klemperer (1995)'in araştırmasının sonuçları da hizmet kalitesine yönelik olumlu algılara sahip müşterilerin bilişsel uyumsuzluğu azaltmak için alternatifleri görmezden gelip, mevcut işletme ile devam ettiğine işaret etmektedir. Tam tersi hizmet kalitesine ilişkin olumsuz deneyim ise müşterileri alternatiflere yönlendirecektir (Aydın ve Özer, 2005). Bu bulgular doğrultusunda aşağıdaki hipotez önerilmektedir:

H7: Tüzel müşterilerin ana bankalarından aldıkları hizmetin kalitesine yönelik algıları ile alternatif bankaların sundukları tekliflerin cazip olarak değerlendirilmesi arasında negatif ve anlamlı bir ilişki bulunmaktadır. 


\subsection{Müşteri Sadakati}

Sadakat "tercih edilen bir ürünü gelecekte de tutarlı bir şekilde yeniden satın alma veya müşterisi olma konusunda derinden duyulan bir bağlılık olmakla birlikte, durumsal etkiler ve potansiyel değiştirme davranışına neden olabilecek pazarlama çabalarına rağmen, aynı marka veya aynı marka setinin tekrar tekrar satın alınmasıdır" (Oliver, 1997: 392). Sadakat bir müşterinin hizmet sağlayıcı ile olan ilişkisine devam etmede gösterdiği kararlılıktır. Bu araştırmada müşteri sadakati; müşterilerin bu bankadan hizmet satın almaya devam etme, gerektiğinde bu bankayı ilk tercih olarak görme, bu bankayı çevrelerine tavsiye etme ve çevrelerini bu banka ile çalışmaya teşvik etme olasılığı olarak işlevselleştirilmiştir. Müşteri sadakati bir bankanın sahip olduğu pazar payı, yeni müşteri kazanımı ve karlıık oranlarında belirleyici bir unsurdur. Bu noktada bankaya sadık olan müşterilerin yeni müşterilere kıyasla şubeleri daha sık ziyaret ettikleri ve işlem yaptıkları, alternatif dağıtım kanallarını daha sık kullandıkları, birden fazla ürün sahiplik ve kullanım düzeyinde oldukları, daha az şikâyet davranışı gösterdikleri ve yeni müşteri kazanımında önemli referans rol oynadıkları düşünülmektedir.

Müşterilerin işletmeye olan sadakatini etkileyen önemli faktörlerden biri işletmenin sahip olduğu kurumsal imajdır. Bir işletmenin sahip olduğu kurumsal imaj, o işletmenin müşterilerini elde tutma ihtimalinde belirleyici rol oynamaktadır (Ball vd., 2006). Hizmet işletmelerinde özellikle müşteriler hizmetin içeriğine ve işlemlere ilişkin yeterli bilgiye sahip olmadıklarında kurumsal imaj müşterilerin satın alma sonrası işletmeye olan bakış açılarında etkili bir unsurdur (Andreassen ve Lindestad, 1998). Geçmişte yapılan araştırmalar işletmenin kurumsal imajı ile müşterilerin işletmeye yönelik sadakatleri arasında güçlü bir ilişki olduğuna işaret etmektedir (Nguyen ve Leblanc, 2001; Richard ve Zhang, 2012). Bu bilgilere dayanarak aşağıdaki hipotez önerilmektedir:

$\boldsymbol{H}_{8}$ : Tüzel müşterilerin ana bankalarına yönelik kurumsal imaj algıları ile ana bankalarına olan sadakatleri arasında pozitif ve anlamlı bir ilişki bulunmaktadır.

Müşterilerin işletmeye ve ürünlerine geliştirdikleri sadakatin şekillenmesinde güven temel basamaklardan biridir. İşletmeye ve ürünlerine güven duymayan bir müşterinin işletmeye ya da ürünlerine sadakat geliştirmesi rasyonel bir davranış değildir. Bu noktada güven ile sadakat arasında doğrusal bir ilişki bulunmaktadır (Doney ve Cannon, 1992; Aydın ve Özer, 2005; Hsu, Ju, Yen ve Chang, 2007). Sadakat, müşterinin alıcısı olduğu işletmenin aralarında çatışma olmayacağı ve beklentilerinin gerçekleştirileceğine ilişkin inanç ve güveninden önemli ölçüde beslenmektedir (Nyugen, Leclerc ve LeBlanc, 2013). Bununla birlikte yapılan araştırmalar incelendiğinde güvenin müşteri tatmini üzerindeki etkisinden yola çıkarak, sadakatin de öncülü olduğuna dikkat çeken araştırmalar (Ranaweera ve Prabhu, 2003; Aydın ve Özer, 2005; Yap vd., 2012, Nguyen vd., 2013) olduğu görülmektedir. Nguyen ve Khoa (2019) da araştırmalarında müşterilerin hizmet sağlayıcılarına olan sadakatini belirleyen en önemli unsurlardan birinin müşterilerin hizmet sağlayıcıya olan güveni olduğuna dikkat çekmektedirler. Bununla birlikte güncel araştırmalar da bankaya olan güvenin, müşterilerin bankaya sadakat geliştirmede etkili olduğuna dikkat çekmektedir (Khoa, 2020; Ghali, 2021). Illgili alan yazına dayanarak aşağıdaki hipotez önerilmektedir:

$\boldsymbol{H}_{9}$ : Tüzel müşterilerin ana bankalarına duydukları güven ile ana bankalarına olan sadakatleri arasında pozitif ve anlamlı bir ilişki bulunmaktadır.

İ̧letmelerin müşterileri ile olan mevcut ilişkilerinin sağlam bir zeminde sürdürülebilirliği için yüksek düzeyde müşteri memnuniyeti ile sonuçlanan hizmetler sağlaması gerekmektedir (Wu, 2014). Hizmet kalitesi yükseldikçe, müşterilerin hizmete ya da işletmeye yönelik sadakati de o oranda yüksek olacaktır. Yüksek hizmet kalitesi, yüksek müşteri tatminin yanı sıra müşteri sadakatini de güçlendirmektedir (Levesque ve McDougall, 1996). İlgili alanyazına dayanarak aşağıdaki hipotez önerilmektedir:

$H_{10}$ : Tüzel müşterilerin ana bankalarından aldıkları hizmetin kalitesine yönelik algıları ile ana bankalarına olan sadakatleri arasında pozitif ve anlamlı bir ilişki bulunmaktadır.

Müşteri tatmini müşteri sadakatine giden yolda güçlü bir belirleyicidir. Aldığı hizmete yönelik tatmin duyan müşterilerin, işletmeye ya da hizmete yönelik sadakat geliştirmeleri de olasıdır. Bu noktada hizmete yönelik tatmin arttıkça, müşterilerin de işletme ya da ürüne yönelik sadakat düzeyinin artması 
beklenmektedir (Parasuraman vd., 1988). Geçmiş araştırmalar incelendiğinde müşteri tatmini ile müşteri sadakati arasında güçlü bir ilişki olduğu görülmektedir (Hallowell, 1996; Lam ve Burton, 2006; Ball vd., 2006; Richard ve Zhang, 2012; Yap vd., 2012). Ayrıca güncel araştırmalar da müşterilerin bankanın ürünlerine yönelik duydukları tatminin, müşterilerin bankaya sadakat geliştirmesini olumlu yönde etkilediğine dikkat çekmektedir (Alkhouli, 2018; Raza vd., 2020; Teeroovengadum, 2020; Ghali, 2021). Bu bilgiler doğrultusunda aşağıdaki hipotez önerilmektedir:

$\boldsymbol{H}_{11}$ : Tüzel müşterilerin ana bankalarından aldıkları hizmete yönelik tatminleri ile ana bankalarına olan sadakatleri arasında pozitif ve anlamlı bir ilişki bulunmaktadır.

Algılanan değiştirme maliyetleri ile sadakat arasındaki ilişki özellikle hizmet sektöründe değiştirme maliyetleri lehine seyretmektedir. Algılanan değiştirme maliyetlerinin yüksek olması müşteri sadakatine katkı sağlayan bir unsurdur (Andreassen ve Lindestad, 1998). Bu noktada hizmetlere yönelik değiştirme maliyetleri düzeyi ile müşteri sadakati arasında pozitif bir ilişki bulunmaktadır (de Ruyter, Wetzels ve Bloemer, 1997). Hatta öyle ki değiştirme maliyetleri yüksek olarak algılandığında, rakip işletmeler aynı ürünü daha uygun fiyatla sunsa bile müşteriler mevcut tedarikçilerinden tekrarlayan satın almalarda bulunmaktadırlar (Klemper, 1995; Aydin ve Özer, 2005). Bazı araştırmalar, işletmelerin hizmet kalitesindeki dalgalanmaların üstesinden gelmesine yardımcı olduğundan, değiştirme maliyetleri yaratılmasının müşteriyi elde tutma stratejilerini tamamlamak için kullanılabileceğini öne sürmektedir (Jones vd., 2002). Bu noktada değiştirme maliyetleri, müşterilerin fiyat düzeyine duyarlılığını doğrudan etkileyen ve dolayısıyla müşteri sadakatini etkileyen önemli bir faktördür (Bloemer vd., 1998; Burnham vd., 2003; Aydın ve Özer, 2005). Bu bilgiler ışığında aşağıdaki hipotez önerilmektedir:

$\boldsymbol{H}_{12}$ : Tüzel müşterilerin ana bankalarını değiştirmeleri durumunda katlanacakları değiştirme maliyetleri ile ana bankalarına olan sadakatleri arasında pozitif ve anlamlı bir ilişki bulunmaktadır.

Müşteri tatmini ve sadakat arasındaki ilişkinin yönünü belirlemede değiştirme maliyetleri etkili bir unsurdur. Müşteriler tarafından algılanan değiştirme maliyetleri seviyesi ne kadar yüksek olursa, müşteri memnuniyeti ve müşteri sadakati arasındaki ilişki de o derece güçlü olmaktadır (Yang ve Peterson, 2004). Bununla birlikte değiştirme maliyetleri tatminin sadakat üzerindeki etkisini azaltabilir (Wang, 2010). Müşteriler, özellikle değiştirme maliyetlerinin yüksek olarak algılandığı işletmelerle tatminsiz bir süreç yaşıyor olsa da işletme ile çalışmaya devam etmektedir (Jackson, 1985). Ya da tam tersi müşteriler değiştirme maliyetlerini düşük ya da zayıf olarak algıladıklarında, memnun olsalar bile işletmeye sadakat göstermeyebilirler. Yapılan araştırmalar müşteri tatmini ile sadakati arasındaki ilişkinin değiştirme maliyetlerinden önemli derecede etkilediğine işaret etmektedir (Lee, Lee ve Feick, 2001). Bu bulgulara dayanarak aşağıdaki hipotez önerilmektedir:

$\boldsymbol{H}_{13}$ : Tüzel müşterilerin ana bankalarını değiştirmeye yönelik algıladıkları değiştirme maliyetleri, müşterilerin ana bankalarına yönelik tatmini ve sadakati arasındaki pozitif ve anlamlı ilişkiyi güçlendirmektedir.

Alternatif işletmelerin sunduğu cazip teklifler, müşterilerin mevcut hizmet sağlayıcıyla olan ilişkisinin devamlılı̆ında (Colgate ve Lang, 2001) ve sadakatinin şekillenmesinde etkilidir (Jones ve Sasser, 1995). Alternatiflerin cazibesi gerçekte müşteri bakış açısında bir referans noktası olduğundan (Rusbult, 1980), müşteriler alternatif işletmelerin cazip önerileri ile karşılaştıkça mevcut işletme ile olan ilişkisinin sürekliliğini sorgulayacaktır. Bu noktada alternatif işletmelerin cazip tekliflerinin müşterilerin mevcut işletmeye yönelik sadakatini olumsuz şekilde etkilemesi beklenmektedir (Wu, 2011). Benzer şekilde rakip alternatifler olmadığında, hizmet sağlayıcı ile mevcut ilişkiyi sonlandırma olasılığı da azalmaktadır (Ping, 1993). Gerçekte müşterilerin işletmenin faaliyet gösterdiği pazarda bir alternatifi olmadığını fark ettiğinde mevcut hizmet sağlayıcı ile olan ilişkisini devam ettirmekten başka seçeneği de bulunmamaktadır (Patterson ve Smith, 2003; Lee, Ahn ve Kim, 2008). İlgili alan yazına dayanarak aşağıdaki hipotez önerilmektedir:

$\boldsymbol{H}_{14}$ : Tüzel müşterilere alternatif bankaların sundukları tekliflerin cazip değerlendirilmesi ile tüzel müşterilerin ana bankalarına yönelik sadakati arasında negatif ve anlamlı bir ilişki bulunmaktadır.

Müşteriler için aynı sektörde faaliyet gösteren alternatif işletmelere yönelmek, sadık müşterilerin gelişimini olumsuz şekilde etkileyecektir. Bu noktada değiştirme maliyetlerinin varlığı ve bu maliyetlerin 
müşteri tarafından güçlü olarak algılanması, alternatiflerin yüksek çekiciliğinin sadakat üzerindeki olumsuz etkisine karşı bir tampon görevi üstlenmektedir (Ghazali, Nguyen, Mutum ve Mohdany, 2016). Müşteriler rakip hizmet sağlayıcıdan cazip bir teklif aldığında mevcut işletmenin kendisine fiyat anlamında haksızlık yaptığını düşünerek, mevcut ilişkisini sonlandırabilir ve rakip işletme ile çalışmaya başlayabilir. Müşteri mevcut ilişkiyi sonlandırmaya karar verdiğinde bu durum zaman, çaba ve para içeren değiştirme maliyetlerine neden olabilir. Bu noktada müşterilerin algıladığı değiştirme maliyetleri gerçekte alternatiflerin cazibesinin sadakat üzerinde yaptığı etkiyi hafifletebilir (Chang, Wong ve Li, 2017). İlgili alan yazına dayanarak aşağıdaki hipotez önerilmektedir:

$\boldsymbol{H}_{15}$ : Tüzel müşterilerin ana bankalarını değiştirmeye yönelik algılandıkları değiştirme maliyetleri, alternatif bankaların cazip teklifleri ile tüzel müssterilerin ana bankalarına yönelik sadakati arasındaki negatif ve anlamlı ilişkiyi hafifletmektedir.

\subsection{Ağızdan Ağıza Pazarlama}

Ağızdan ağıza pazarlama (Word-of-mouth; WOM), gerçek veya potansiyel tüketici ile ürün veya hizmet sağlayıcılar, aile ve arkadaş çevresi gibi kişiler arasındaki sözlü iletişimi ifade etmektedir (Helm ve Schlei, 1998). Ağızdan ağıza pazarlama olumlu ya da olumsuz şekilde gerçekleşebilir. Müşterilerin işletmeyi ya da ürünleri çevresine olumlu tavsiyesi olumlu ağızdan ağıza pazarlama iken, müşteriler işletme ya da ürünlerini çevrelerine şikâyet ettiklerinde bu olumsuz ağızdan ağıza pazarlama olarak değerlendirilmektedir (Kitapçı, Akdoğan ve Dörtyol, 2014). Ağızdan ağıza pazarlama müşterilerin satın alma tutum ve davranışlarına önemli ölçüde şekil vermektedir. Özellikle hizmet alanında müşteriler hizmeti deneyimlemeden ya da satın almadan önce bu hizmeti deneyimlemiş müşterilerin görüşleri almaktadır. Diğer bireylerden alınan işletme ya da ürüne ilişkin olumlu geri bildirimler müşterilerin satın alma kararlarındaki belirsizliği ve riski azaltmaktadır (Murray, 1991). Bu noktada özellikle hizmet işletmelerinin müşteride yaratacağı olumlu ağızdan ağıza pazarlama işletmenin kendisi ve ürünleri için hayati önem taşımaktadır (Berry ve Pasuraman, 1991).

Satın aldığı hizmetten tatmin olan müşterilerin, çevresine de işletme ve ürünleri hakkında olumlu geri bildirimde bulunması beklenmektedir (Parasuraman vd., 1988). Bu noktada satın aldığı hizmetin kalitesine ilişkin algısı yüksek olan ve satın aldığı hizmetten tatmin olan müşteriler çevresine olumlu geri bildirimde bulunmakta, hatta çevresini de o işletmenin ürünlerini deneyimlemeye yöneltmektedir (Lovelock, Vandermerwe ve Lewis, 1996). Bununla birlikte satın aldığı hizmete yönelik hayal kırıklığı yaşamış müşterilerin deneyimleri de işletme ve ürünleri hakkında olumsuz ağızdan ağıza pazarlama yol açmaktadır (Walker, 1995). Gerçekte olumlu hizmet kalitesi deneyimleyen müşterilerin hizmeti ya da hizmet işletmesini bir başkasına tavsiye etme istekliliği de artmaktadır (Levesque ve McDougall, 1996). Bankacılık alan yazınına ilişkin güncel araştırmalar (Mahadin ve Akroush, 2018; Mukerjee, 2020; Rajaobelina vd., 2021) da müşterilerin bankanın hizmet kalitesine ilişkin olumlu algıları arttıkça, müşterilerin bankayı çevrelerine tavsiye eğiliminin de arttığına işaret etmektedir. Bu bağlamda müşterilerin tavsiye davranışında algılanan hizmet kalitesi önemli bir unsurdur (Solunoğlu, 2020). Bu bilgiler doğrultusunda aşağıdaki hipotez önerilmektedir:

$H_{16}$ : Tüzel müşterilerin ana bankalarından aldıkları hizmetin kalitesine yönelik algıları ile ana bankaları hakkında çevrelerine olumlu konuşmaları arasında pozitif ve anlamlı bir ilişki bulunmaktadır.

Sadakat ilişki kalitesinin bir göstergesi olup (Casidy ve Wymer, 2015), ağızdan ağıza pazarlama müşteri sadakatinin alt boyutu olarak da kabul edilmektedir (Kitapçı vd. 2014). Ayrıca ağızdan ağıza pazarlama pek çok araştırmacı tarafından da tekrarlayan satın alma davranışının sonuç boyutu olarak kabul edilmektedir (Dick ve Basu, 1994). Yapılan araştırmalar olumlu ağızdan ağıza pazarlama davranışında bulunan müşterilerin işletme ya da işletmenin ürünlerine sadık olan müşteriler olduğuna işaret etmektedir (Gremler, 1995; Gremler ve Brown, 1996; Srinivasan, Anderson ve Ponnavolu, 2002). Bankacilik alanında yapılan çalışmalar (Trabelsi-Zoghlami, Berraies ve Yahia, 2020) incelendiğinde de müşterilerin bankaya yönelik sadakatinin, ağızdan ağıza pazarlama davranışını olumlu yönde etkilediği görülmektedir. Müşterilerin bankaya yönelik sadakati attıkça, müşteriler bankaya yönelik çevrelerine daha olumlu bilgiler vermekte ve bankayı yakınlarına 
ve çevrelerine tavsiye etmektedirler (Blut, 2016; Ifi, Simintiras, Dwivedi ve Mavridou, 2018; Loureiro, Cavallero ve Miranda, 2018). İgili alan yazına dayanarak aşă̆ıdaki hipotez önerilmektedir:

$\boldsymbol{H}_{17}$ : Tüzel müşterilerin ana bankalarına yönelik sadakatleri ile ana bankaları hakkında çevrelerine olumlu konuşmaları arasında pozitif ve anlamlı bir ilişki bulunmaktadır.

\section{Araştırma Metodolojisi}

\subsection{Araştırmanın Amacı}

Tüzel müşteriler kendilerine sunulan hizmetin çeşitliliği, bankaların farklı satış ve operasyonel kanallarından hizmet alma ihtiyacında olmaları ve işletmeyi temsil eden birden fazla kişinin (ortaklar, finansman müdürü, işlem yetkilisi, vb.) beklentilerinin karşılanması gibi sebeplerden ötürü bireysel müşterilerden farklılaşmaktadır. Bu durum bankaların da tüzel müşterilere özel müşteri devamlıığını sağlayıcı stratejiler geliştirmelerini zorunlu kılmaktadır. Bununla birlikte günümüzde işletmeler iş yapış biçimleri, zorunluluklar ya da kendi tercihlerinden ötürü birden fazla banka ile çalışmaktadırlar. İşletmelerin nakit akışı ya da kredi büyüklüğünde daha büyük paya sahip olan banka ise o işletmenin ana bankası olarak kabul edilmektedir. Bir işletmenin ana bankası olmak ve bunu sürdürmek bankalar için adet, hacim ve karlılık hedeflerine ulaşma konusunda önemli bir hedeftir. Bu nedenlerden hareketle araştırmanın amacı tüzel müşterilerin ana bankalarından aldıkları hizmetin kalitesi ile müşteri güveni, müşteri tatmini, kurumsal imaj, değiştirme maliyetleri ve alternatiflerin çekiciliği arasındaki ilişkileri belirlemek ve müşteri sadakatinin belirleyicilerini de bu değişkenler doğrultusunda ortaya koymaktır. Günümüzde bankalar birbirine çok benzer ürünleri müşteri hizmetine sunarken, hizmet kalitesini yükselterek müşteri tatmini ve müşteri sadakati yaratmayı en önemli stratejilerinden biri olarak benimsemektedirler. Bu noktada bankalar müşterilerinin kendileri ile çalışmaya devam etmesi ve özellikle de ana bankaları olmalarını sürdürmek için değiştirme maliyetleri yaratmaktadırlar. Araştırmanın bir diğer amacı da bu bağlamda algılanan değiştirme maliyetlerinin müşteri tatmini ve müşteri sadakati arasında ve alternatif bankaların sunduğu cazip tekliflerle müşteri sadakati arasındaki ilişkideki rolünü ortaya çıkarmaktır. Müşterilerin gerek kendi sadakatlerinin göstergesi, gerekse bankaların yeni müşteri kazanımında etkisi olduğu düşünülen ağızdan ağıza pazarlama davranışında müşterilerin algıladıkları hizmetin kalitesinin ve müşteri sadakatinin etkisinin ölçülmesi de bu bağlamda araştırmanın bir diğer amacıdır. Bu doğrultuda bankalar için gerek hacim gerekse kar yaratmada önemli olan tüzel müşterilerin, alan yazına bireysel müşteriler kadar konu olmaması ve bu değişkenler kapsamında yeteri kadar incelenmemiş olmaması araştırmanın özgün tarafını ortaya koymaktadır.

\subsection{Araştırma Modeli ve Ölçekler}

Araştırmada kullanılan ölçek ifadeleri daha önceden geçerliliği ve güvenilirliği sınanmış ölçeklerden oluşmakta olup, ölçekler ankete dâhil edilmeden önce İngilizce-Türkçe ve Türkçe-İngilizce çevirilerinin karşılığı ve anlam bütünlüğü konusunda Ufuk Üniversitesi İngilizce Çevirmenlik bölümü öğretim üyelerinden uygunluk alınmıştır. Ankette kullanılan ölçeklerden algılanan hizmet kalitesi ölçeği (17 ifade) Bloemer vd. (1998)'nin çalışmasından, kurumsal imaj ölçeği (5 ifade) Bayol, LaFoye, Tellier ve Tenenhaus (2001)'un çalışmasından, müşteri güveni ölçeği (5 ifade) Aydın ve Özer (2005)'in çalışmasından, müşteri tatmini ölçeği (3 ifade) Oliver ve Swan (1989)'ın çalışmasından, algılanan değiştirme maliyetleri (5 ifade) ve alternatiflerin çekiciliği (5 ifade) ölçekleri Ping (1993)'in çalışmasından, müşteri sadakati ölçeği (5 ifade) Narayandas (1996)'ın çalışmasından ve ağızdan ağıza pazarlama ölçeği (3 ifade) ise Yi ve Gong (2013)'un çalışmasından alınmıştır.

Alan yazın incelemesine dayanarak hazırlanan araştırma modeli Şekil 1'de gösterilmektedir. 
Şekil 1. Araştırma Modeli

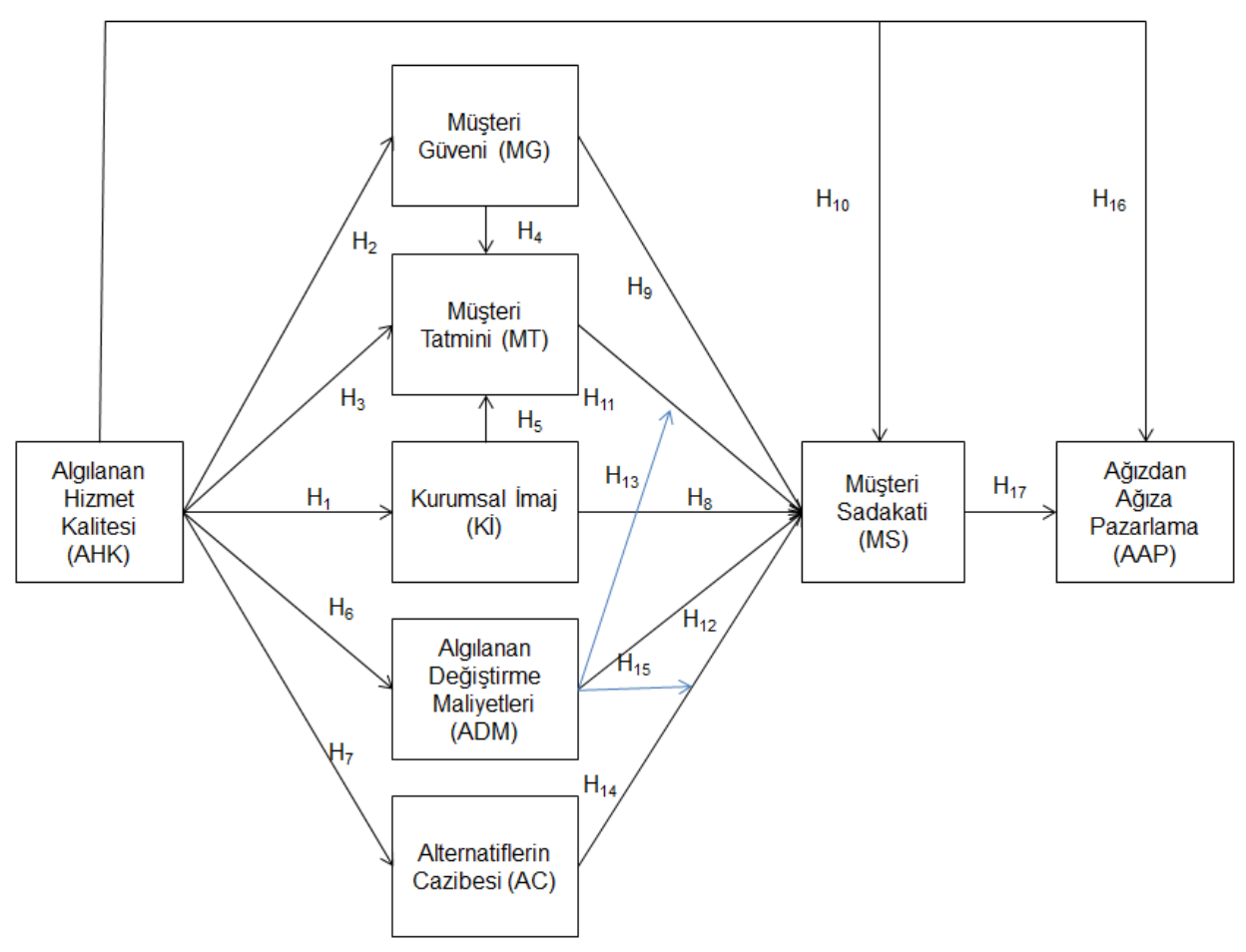

Kaynak: Yazar tarafından oluşturulmuştur.

\subsection{Veri Toplama Yöntemi ve Örneklem}

Nicel araştırma kapsamında olan araştırmada, veri toplama yöntemi olarak anket kullanılmıştır. Tüzel kişilikte çok sayıda müşteri olduğu göz önüne alındığında evrenin tamamına ulaşmanın mümkün olmaması nedeniyle tesadüfi olmayan örnekleme yöntemlerinden kolayda örnekleme yöntemi kullanılmıştır. Anket çalışması Eylül-Ekim 2020 döneminde yürütülmüş olup, anket uygulaması öncesinde Ufuk Üniversitesi Sosyal ve Beşeri Bilimler Bilimsel Araştırma ve Yayın Etiği Kurulu'ndan 24.09.2020 tarihinde 2020/63 sayılı karar ile Etik Kurul onayı alınmıştır. Anket iki bölümden oluşmaktadır. Anketin birinci bölümünde tüzel müşterilerin ana bankalarını değerlendirmeye yönelik ifadeleri, ikinci bölümünde ise bu müşterilerin işletme bilgilerine yönelik ifadeleri içermektedir. Ankette yeralan ifadeler 5'li Likert yöntemi ile ölçümlenmiştir (1: Kesinlikle katılmıyorum, 5: Kesinlikle katılıyorum).

Araştırmanın örneklemini Türkiye'deki bankalardan hizmet alan Ankara'da yerleşik tüzel müşteriler oluşturmaktadır. Ankara Sanayi ve Ticaret Odası'na kayıtı işletmelerden e-posta iletişim bilgilerine ulaşılan 1800 işletmenin ortaklarına veya finans yöneticilerine anket formu gönderilmiş ve ankete 261 işletme katılmıştır. Veri kontrolünde yanlış/eksik cevap veren 9 işletmenin anket formları elenmiş ve kalan 252 katılımcı işletme ile analize devam edilmiştir. Ankette 47 madde bulunmaktadır. Kline'a (1994) göre örneklemin toplam parametre sayısının 2-10 katı olması, hatta ankette en az 200 katılımcının yeralması yeterlidir. Bu noktada 94-470 katılımcıya ulaşmanın yeterli bir kriter olduğu bilinmektedir (Kline, 1994).

Araştırmaya katılan işletmeler ile ilgili bilgiler Tablo 1'de gösterilmektedir. Tablo 1'e göre işletmelerin $\% 76$ 'sı ana bankaları ile 5 yıldan uzun süredir çalışmaktadır ve \%96'sının ortaklık yapısı Türk sermayesinden oluşmaktadır. Ayrıca araştırmaya katılan işletmelerin \%46,1'inin 250 'den fazla çalışanı, \%43,3'ünün 125 milyon TL'nin üzerinde cirosu ve \%54,3'ünün 10 milyon TL'nin üzerinde nakit kredi borcu bulunmaktadır. Ciro ve kredi riski sınıflandırması KOSGEB'in (Küçük ve Orta Ölçekli İşletmeleri Geliştirme ve Destekleme İdaresi) Küçük ve Orta Ölçekli İşletmeler sınıflandırmasına göre yapılmıştır (KOSGEB, 2018). 
Tablo 1. Katılımcıların Özellikleri $(n=252)$

\begin{tabular}{|c|c|c|c|c|c|c|c|c|}
\hline \multicolumn{3}{|c|}{ Ana Bankası ile Çalışma Süresi } & \multicolumn{3}{|c|}{ Yabancı Ortaklık } & \multicolumn{3}{|c|}{ Çalışan Sayısı } \\
\hline & $\mathbf{N}$ & $\%$ & & $\mathbf{N}$ & $\%$ & & $\mathbf{N}$ & $\%$ \\
\hline$<3$ yıl & 28 & 11 & Evet & 11 & 4 & 0-50 kişi & 87 & 34,5 \\
\hline 3-5 yıl & 32 & 13 & Hayır & 241 & 96 & 51-250 kişi & 49 & 19,4 \\
\hline$>5$ yıl & 192 & 76 & & & & >250 kişi & 116 & 46,1 \\
\hline \multicolumn{3}{|c|}{2019 Cirosu (Milyon TL) } & \multicolumn{3}{|c|}{$\begin{array}{c}\text { Nakit Kredi Borcu } \\
\text { (MilyonTL) }\end{array}$} & & & \\
\hline & $\mathbf{N}$ & $\%$ & & $\mathbf{N}$ & $\%$ & & & \\
\hline 0-12 mln TL & 55 & 21,8 & 0-1 mln TL & 67 & 26,5 & & & \\
\hline 12-125 mln TL & 88 & 34,9 & 1-10 mln TL & 48 & 19,2 & & & \\
\hline$>125 \mathrm{mln} \mathrm{TL}$ & 109 & 43,3 & $>10 \mathrm{mln} \mathrm{TL}$ & 137 & 54,3 & & & \\
\hline
\end{tabular}

\section{Bulgular}

\subsection{Betimleyici Analiz, Güvenilirlik ve Geçerlilik, Açıklayıcı ve Doğrulayıcı Faktör Analizi}

Araştırmada öncelikle modeli oluşturan değişkenlerin çarpıklık ve basıklık değerleri kontrol edilmiş ve Açıklayıcı Faktör Analizi (AFA) uygulanmıştır. Çarpıklık ve basıklık değerleri -2 ile +2 arasında olduğunda veri dağııımı normaldir (George ve Mallery, 2010). Analiz bulgularına göre her maddenin kendi faktörlerine yüklendiği görülmüştür. Bununla birlikte faktör yükü 0,70'ın altında kalan yedi adet algılanan hizmet kalitesi ölçeğine ilişkin gösterge ve bir adet müşteri sadakati ölçeğine ilişkin gösterge analiz dışı bırakılmıştır. Bu sekiz gösterge dışındaki tüm göstergelerin faktör yükleri 0,70'ın üzerindedir. Daha sonra ölçüm modelinin gerekli koşulları karşılayıp karşılamadığını test etmek için Doğrulayıcı Faktör Analizi (DFA) ile modeldeki gizil değişkenler üzerinde geçerlilik ve güvenilirlik analizleri yapılarak ölçüm modeli test edilmiştir. Değişkenler ve hipotezler arasındaki ilişkiyi test etmek için, değişkenler arası korelasyon analizi yapıldıktan sonra verilere YEM (Yapısal Eşitlik Modeli) uygulanmıştır. Araştırma modelini değerlendirmek için çalışmada kısmi en küçük kareler (PLS, SmartPLS Sürüm 2.0) yöntemi kullanılmıştır. SmartPLS'yi seçmenin en önemli nedeni, araştırmada oluşturulan modelin öngörü gücünü vurgulayabilmesidir (Chin, Marcolin ve Newsted, 1996).

DFA ile 8 gizil değişken ve toplam 40 göstergeden oluşan bir ölçüm modeli değerlendirilmiştir. Araştırma amacıyla oluşturulan modelin araştırma verilerine ne ölçüde karşlık geldiğini anlamak için uyum indeksleri değerlendirilmiştir. SmartPLS programı ile NFI ve SRMR değerleri elde edilmiştir. Ulaşılan NFI $(0,962)$ ve SRMR $(0,061)$ değerleri modelin kabul edilebilir uyumunu göstermektedir (Kline, 1998). Bu veriler ışığında veri setinin teorik ölçme modelini desteklediği düşünülmektedir.

Birinci düzey değişkenlerin üst düzey faktör yapısına dönüştürülmesinde iç tutarlılık (Cronbach $\alpha$ ) değeri ölçüt olarak alınmaktadır. (Brakus, Schmitt ve Zarantonello, 2009). Çalışmada açıklanan ortalama varyans (AVE) ve bileşik güvenilirlik (CR) değerleri de DFA kapsamında kontrol edilerek Tablo 2'de gösterilmiştir. Buna göre ölçeklerin güvenirliği 0,914 ile 0,981 arasındadır ve kabul edilebilir değer olan 0,70'ten büyüktür. Bu, bileşik güvenilirlik için önemli bir kanıttır (Hair, Hult, Ringle ve Sarstedt, 2014) ve ölçeklerin kabul edilebilir güvenilirlikte olduğuna işaret etmektedir (Bagozzi ve Yi, 1988). Son olarak, yakınsak geçerliliğini kontrol etmek için her ölçek için AVE değerleri kontrol edilmiştir. Buna göre, tüm ölçeklerin AVE değerleri kabul edilebilir minimum değer olan 0,50'nin üzerinde olduğu için, ölçeklerin AVE değeri, değişkenlerin faktör yükleri ve Cronbach $\alpha$ değerlerinin bir sonucu olarak modelin yakınsak geçerliliği de doğrulanmıştır (Hair vd., 2014). 
Tablo 2. Ölçeklere iliş̧kin DFA Sonuçları

\begin{tabular}{lcccccc}
\hline Değişkenler & $\begin{array}{c}\text { Gösterge } \\
\text { sayısı }\end{array}$ & $\begin{array}{c}\text { Faktör } \\
\text { yükleri }\end{array}$ & AVE & CR & $\boldsymbol{\alpha}$ & KMO \\
\hline Algılanan Hizmet Kalitesi (AHK) & 10 & $0,71-0,90$ & 0,630 & 0,944 & 0,883 & 0,885 \\
Kurumsal İmaj (Ki) & 5 & $0,83-0,87$ & 0,718 & 0,927 & 0,902 & 0,796 \\
Müşteri Güveni (MG) & 5 & $0,85-0,93$ & 0,792 & 0,950 & 0,934 & 0,855 \\
Müşteri Tatmini (MT) & 3 & $0,95-0,98$ & 0,939 & 0,979 & 0,967 & 0,761 \\
Algılanan Değiştirme Maliyetleri & & & & & & \\
(ADM) & 5 & $0,79-0,87$ & 0,680 & 0,914 & 0,883 & 0,854 \\
Alternatiflerin Cazibesi (AC) & 5 & $0,89-0,98$ & 0,903 & 0,979 & 0,973 & 0,898 \\
Müşteri Sadakati (MS) & 4 & $0,90-0,97$ & 0,861 & 0,961 & 0,946 & 0,803 \\
Ağızdan Ağıza Pazarlama (AAP) & 3 & $0,96-0,98$ & 0,945 & 0,981 & 0,971 & 0,749 \\
\hline P<0,01
\end{tabular}

$\mathrm{p}<0,01$

Yakınsak geçerlilik sağlandıktan sonra, bir boyutun diğer boyutlardan ne kadar ayırt edilebileceğini incelemek için değişkenlerin ayırt edici geçerliliği incelenmiştir. Bir boyut için ortalama artık varyansın karekökü, bu boyut ile diğer boyutlar arasındaki korelasyonun karesinden daha büyük olmalıdır (Cooper ve Zmud, 1990). Analiz sonucunda elde edilen değerler Tablo 3 'te gösterilmiştir. AVE değerlerinin karekökü korelasyonların karesinden daha büyük olarak elde edilmiş ve bu durumda ayırt edici geçerlilik sağlanmıştır.

Tablo 3. Ayırt Edici Geçerlilik Analizi Sonuçları

\begin{tabular}{lcccccccc}
\hline Değişkenler & ADM & AHK & AÇ & AAP & Ki & MG & MS & MT \\
\hline ADM & 0,825 & & & & & & & \\
AHK & 0,374 & 0,794 & & & & & & \\
AC & 0,613 & 0,295 & 0,950 & & & & & \\
AAP & 0,407 & 0,869 & 0,319 & 0,972 & & & & \\
Ki & 0,491 & 0,848 & 0,421 & 0,770 & 0,847 & & & \\
MG & 0,366 & 0,901 & 0,287 & 0,888 & 0,789 & 0,890 & & \\
MS & 0,448 & 0,909 & 0,434 & 0,944 & 0,831 & 0,898 & 0,928 & \\
MT & 0,409 & 0,891 & 0,343 & 0,915 & 0,805 & 0,889 & 0,908 & 0,969 \\
\hline AVE & $\mathbf{0 , 6 8 0}$ & $\mathbf{0 , 6 3 0}$ & $\mathbf{0 , 9 0 3}$ & $\mathbf{0 , 9 4 5}$ & $\mathbf{0 , 7 1 8}$ & $\mathbf{0 , 7 9 2}$ & $\mathbf{0 , 8 6 1}$ & $\mathbf{0 , 9 3 9}$ \\
\hline
\end{tabular}

\subsection{Hipotezlerin Test Edilmesi}

YEM'e geçmeden önce modelin uyum değerleri incelenmiştir. Buna göre, kurulan yol analizi modeline ilişkin uyumluluk indeksleri ( $N F I=0,962, S R M R=0,061$ ) elde edilmiştir. Modelin uyum kontrolü için NFI ve SRMR değerlerinin yanı sıra d_ULS ve d_G değerleri de incelenmiştir. Modelin iyi uyum sağlaması için, güven aralığının üst sınırı, d_ULS ve d_G tam uyum kriterlerinin orijinal değerinden daha büyük olması gerekmektedir. Bu nedenle güven aralığının üst sınırı \%95 veya \%99 olarak seçilmiştir. Modelin korelasyon matrisi ile ampirik korelasyon matrisi arasındaki fark istatistiksel olarak anlamsız olduğunda $(p>0,05)$ modelin uygun olduğu belirtilmektedir. D_ULS ve d_G tam uyum kriterleri için hesaplanan 4.830 ve 6.237 değerleri p>0,05'tir. Ki-kare değeri 2.920,847'dir. Elde edilen model uyum değerleri Tablo 4'te gösterilmiştir. Tablo 4'e göre modelin iyi uyum sağladığı düşünülmektedir (Kline, 1998). 
Tablo 4. Model Uyumluluk İndeksi

\begin{tabular}{lc}
\hline Uyumluluk indeksi & indeks Değeri \\
\hline NFI & 0,962 \\
SRMR & 0,061 \\
d_ULS & 4.830 \\
d_G & 6.237 \\
Chi-square $(x 2)$ & $2.920,85$ \\
\hline p $>0,05$ &
\end{tabular}

Değişkenler arasındaki ilişki Pearson korelasyon katsayısı kullanılarak analiz edilmiştir. Bu yöntem, değişkenler sürekli olduğunda ve örneklem büyüklüğü yeterli olduğunda $(n>30)$ veriler arasındaki ilişkiyi incelemek için kullanılan parametrik bir yöntemdir. Tüm değişkenler arasındaki ilişki \%99 güven aralığında ( $p$ $<0,01$ ve $p<0,05$ ) istatistiksel olarak anlamlıdır ve tüm korelasyon değerleri pozitiftir. Yapısal eşitlik modelleri ve regresyondaki önemli varsayımlardan biri, yordanan değişkenler ile yordayıcı değişkenler arasında anlamlı bir ilişki olması gerektiğidir. Sonuçlar Tablo 5 'te gösterilmiştir. Buna göre değişkenler arasındaki en yüksek ilişki müşteri sadakati ile ağızdan ağıza pazarlama arasındadır ve korelasyon katsayısı r =0,944'dür.

Tablo 5. Korelasyon Analizi Sonuçları

\begin{tabular}{lcccccccc}
\hline Değişkenler & AHK & Ki & MG & MT & ADM & AÇ & MS & AAP \\
\hline AHK & 1 & & & & & & & \\
Ki & $0,830^{* *}$ & 1 & & & & & & \\
MG & $0,903^{* *}$ & $0,769^{* *}$ & 1 & & & & & \\
MT & $0,892^{* *}$ & $0,793^{* *}$ & $0,891^{* *}$ & 1 & & & & \\
ADM & $0,355^{* *}$ & $0,472^{* *}$ & $0,359^{* *}$ & $0,395^{* *}$ & 1 & & & \\
AC & $0,283^{*}$ & $0,419^{* *}$ & $0,288^{*}$ & $0,339^{* *}$ & $0,616^{* *}$ & 1 & & \\
MS & $0,907^{* *}$ & $0,820^{* *}$ & $0,896^{* *}$ & $0,908^{* *}$ & $0,437^{* *}$ & $0,431^{* *}$ & 1 & \\
AAP & $0,868^{* *}$ & $0,758^{* *}$ & $0,887^{* *}$ & $0,916^{* *}$ & $0,393^{* *}$ & $0,316^{* *}$ & $0,944^{* *}$ & 1 \\
\hline
\end{tabular}

${ }^{* *} p<0,01,{ }^{*} p<0,05$

Bağımsız değişkenlerin bir kısmının kendi arasında yüksek ilişkiler gözlemlenmesinden ötürü çoklu bağlantı problemi olup olmadığını analiz etmek için Tolerans ve VIF değerleri kontrol edilmiştir. Tolerans değerinin 0,10 'dan küçük olması ve VIF değerinin 10'dan büyük olması çoklu bağlantı problemi olduğunu gösterir (Tabachnick ve Fidell, 2013). Elde edilen sonuçlar Tablo 6'da gösterilmiştir. Tablo 6'ya göre çoklu bağlantı problemi gözlemlenmemiştir.

Tablo 6. Çoklu Bağlantı Analizi Sonuçları

\begin{tabular}{lcc}
\hline & VIF & Tolerans \\
\hline ADM & 1,801 & 0,555 \\
AHK & 8,85 & 0,111 \\
AC & 1,68 & 0,486 \\
AAi & 3,556 & 0,198 \\
Ki & 4,289 & 0,258 \\
MG & 6,582 & 0,139 \\
MS & 5,786 & 0,057 \\
\hline
\end{tabular}


Hipotezleri test etmek için kısmi en küçük kareler (PLS) yapısal eşitlik modellemesi kullanılmıştır. PLS ile hem doğrudan hem de dolaylı olarak oldukça karmaşık öngörücü modelleri ve çok unsurlu yapıları analiz etmek mümkündür. Analizde tüzel müşterilerin ana bankalarına olan sadakatlerini belirleyen unsurlar algılanan hizmet kalitesi, kurumsal imaj, müşteri güveni, müşteri tatmini, algılanan değiştirme maliyetleri ve alternatiflerin çekiciliği kapsamında incelenmiş olup, ayrıca algılanan hizmet kalitesi, müşteri sadakati ve ağızdan ağıza pazarlama arasındaki ilişki de araştırılmıştır. Analiz sonucu elde edilen regresyon katsayılarından anlamlılıkları ve anlamlılık düzeyleri Tablo 7'de gösterilmiştir.

Tablo 7'ye göre algılanan hizmet kalitesi ve müşteri güveni ile müşteri tatmini arasındaki ilişki anlamlı olup $(\beta=0,368, p<0,05$ ve $\beta=0,451, p<0,01), \mathrm{H}_{3}$ ve $\mathrm{H}_{4}$ hipotezleri desteklenmektedir. Bu sonucun aksine kurumsal imaj ile tatmin arasındaki ilişki anlamlı değildir $(\beta=0,138, p>0,05)$ ve $H_{5}$ hipotezi desteklenmemektedir. Algılanan hizmet hizmet kalitesi ile kurumsal imaj, müşteri güveni, algılanan değiştirme maliyetleri ve alternatiflerin cazibesi değişkenleri arasındaki ilişkiler anlamlı olup $(\beta=0,847 p<0,01$; $\beta=0,901 \quad p<0,01 ; \quad \beta=0,374 p<0,01 ; \quad \beta=-0,295 \quad p<0,05)$, bu nedenle $H_{1}, H_{2}, H_{6}$ ve $H_{7}$ hipotezleri desteklenmektedir. Analiz sonuçları algılanan hizmet kalitesi ile müşteri sadakati, müşteri tatmini ile müşteri sadakati ve alternatiflerin cazibesi ile müşteri sadakati arasındaki ilişkilerin anlamlı olduğunu gösterdiğinden $(\beta=0,329 p<0,05 ; \beta=0,297 p<0,05$ ve $-0,141 p=0,05) H_{10}, H_{11}$ ve $H_{14}$ hipotezleri desteklenmektedir. Ancak kurumsal imaj, müşteri güveni ile algılanan değiştirme maliyetleri ve müşteri sadakati arasındaki ilişkiler anlamlı olmadığından $(\beta=0,056 p>0,05 ; 0,254 p>0,05$ ve $\beta=-0,001 p>0,05) H_{8}, H_{9}$ ve $H_{12}$ hipotezleri desteklenmemektedir. Sonuçlar müşteri sadakati ile ağızdan ağıza pazarlama arasındaki anlamlı ilişkiyi $(\beta=0,892 p<0,01)$ ve algılanan hizmet kalitesi ile ağızdan ağıza pazarlama arasındaki anlamlı ilişkinin yokluğuna $(\beta=0,057 \quad p>0,05)$ işaret ettiğinden, $H_{17}$ hipotezi desteklenmesine rağmen $H_{16}$ hipotezinin desteklenmemektedir.

Tüzel müşterilerin ana bankalarına yönelik yapılan araştırmada müşteri tatmini, müşteri sadakati ve ağızdan ağıza pazarlama için $R^{2}$ değerleri sırasıyla $0,841,0,900$ ve 0,891 olarak elde edilmiştir. Diğer bir deyişle, müşteri tatmininin $\% 84,1^{\prime} i$, müşteri sadakatinin $\% 90^{\prime} ı$ ve ağızdan ağıza pazarlama değişkeninin $\% 89,1$ 'i ilgili değişkenlerle açıklanmıştır.

Analizde son olarak moderatör etkilerin varlığı araştırılmıştır. Tablo 7'ye göre müşteri tatmini ile müşteri sadakati arasındaki ilişkide algılanan değiştirme maliyetlerinin moderatör etkisi anlamlı $(\beta=0,65$ $p<0,05)$ olup $\mathrm{H}_{13}$ hipotezi desteklenmektedir. Buna rağmen alternatiflerin cazibesi ile müşteri sadakati arasındaki ilişkide algılanan değiştirme maliyetlerinin moderatör etkisi anlamlı olmadığından $(\beta=0,051$ $\mathrm{p}>0,05) \mathrm{H}_{15}$ hipotezi de desteklenmemektedir.

Tablo 7. Standartlaştırılmış Parametre Kestirimleri ve Anlamlılık Değerleri

\begin{tabular}{|c|c|c|c|c|c|}
\hline Hipotezler & $\boldsymbol{\beta}$ & $\mathbf{T}$ & $\mathbf{p}$ & $\mathbf{R}^{2}$ & Sonuç \\
\hline $\mathrm{H}_{1}$ Algılanan Hizmet Kalitesi -> Kurumsal İmaj & 0,847 & 19,047 & $0,000 *$ & & Hipotez desteklenmektedir. \\
\hline $\mathrm{H}_{2}$ Algılanan Hizmet Kalitesi -> Müşteri Güveni & 0,901 & 37,145 & $0,000 *$ & & Hipotez desteklenmektedir. \\
\hline $\mathrm{H}_{3}$ Algılanan Hizmet Kalitesi -> Müşteri Tatmini & 0,368 & 3,181 & $0,002 *$ & 0,841 & 1 Hipotez desteklenmektedir. \\
\hline $\mathrm{H}_{4}$ Müşteri Güveni -> Müşteri Tatmini & 0,451 & 4,607 & $0,000^{*}$ & & Hipotez desteklenmektedir. \\
\hline $\mathrm{H}_{5}$ Kurumsal İmaj -> Müşteri Tatmini & 0,138 & 1,429 & 0,153 & & Hipotez desteklenmemektedir. \\
\hline $\mathrm{H}_{6}$ Algılanan Hizmet Kalitesi -> Algılanan Değiştirme Maliyetleri & 0,374 & 4,145 & $0,000 *$ & & Hipotez desteklenmektedir. \\
\hline $\mathrm{H}_{7}$ Algılanan Hizmet Kalitesi -> Alternatiflerin Cazibesi & $-0,295$ & 2,246 & $0,025 * *$ & & Hipotez desteklenmektedir. \\
\hline $\mathrm{H}_{8}$ Kurumsal İmaj -> Müşteri Sadakati & 0,056 & 0,663 & 0,507 & 0,900 & Hipotez desteklenmemektedir. \\
\hline $\mathrm{H}_{9}$ Müşteri Güveni -> Müşteri Sadakati & 0,254 & 1,764 & 0,078 & & Hipotez desteklenmemektedir. \\
\hline $\mathrm{H}_{10}$ Algılanan Hizmet Kalitesi -> Müşteri Sadakati & 0,329 & 2,183 & $0,029 * *$ & & Hipotez desteklenmektedir. \\
\hline
\end{tabular}


Tablo 7. Standartlaştırılmış Parametre Kestirimleri ve Anlamlılık Değerleri (Devam)

\begin{tabular}{|c|c|c|c|c|c|}
\hline Hipotezler & $\boldsymbol{\beta}$ & $\mathbf{T}$ & p & $\mathbf{R}^{2}$ & Sonuç \\
\hline $\mathrm{H}_{11}$ Müşteri Tatmini -> Müşteri Sadakati & 0,297 & 2,390 & 0,017 & & Hipotez desteklenmektedir. \\
\hline $\mathrm{H}_{12}$ Algılanan Değiştirme Maliyetleri -> Müşteri Sadakati & $-0,001$ & 0,078 & 0,938 & & Hipotez desteklenmemektedir. \\
\hline $\begin{array}{l}\mathrm{H}_{13} \text { Algılanan Değiştirme Maliyetlerinin moderator etkisi } \\
\text { Müşteri Tatmini -> Müşteri Sadakati }\end{array}$ & 0,065 & 1,973 & $0,034 * *$ & & Hipotez desteklenmektedir. \\
\hline $\mathrm{H}_{14}$ Alternatiflerin Cazibesi -> Müşteri Sadakati & $-0,141$ & 2,789 & $0,005^{*}$ & & Hipotez desteklenmektedir. \\
\hline $\begin{array}{l}\mathrm{H}_{15} \text { Algılanan Değiştirme Maliyetlerinin moderator etkisi } \\
\text { Alternatiflerin Cazibesi -> Müşteri Sadakati }\end{array}$ & 0,051 & 1,570 & 0,117 & & Hipotez desteklenmemektedir. \\
\hline $\mathrm{H}_{16}$ Algılanan Hizmet Kalitesi -> Ağızdan Ağıza Pazarlama & 0,057 & 0,698 & 0,485 & 0,891 & Hipotez desteklenmemektedir. \\
\hline $\mathrm{H}_{17}$ Müşteri Sadakati -> Ağızdan Ağıza Pazarlama & 0,892 & 11,177 & $0,000^{*}$ & & Hipotez desteklenmektedir. \\
\hline
\end{tabular}

\section{Sonuç ve Öneriler}

Araştırma tüzel müşterilerin ana bankalarına olan sadakatlerini belirleyen unsurları ortaya koymak amacıyla tasarlanmıştır. Bu amaç kapsamında müşterilerin ana bankalarının sunduğu hizmete yönelik algıladıkları hizmet kalitesi, bankanın kurumsal imajı, müşterilerin bankaya ve bankanın duyduğu güven, tatmin ve bankanın ayrılma engelleri olarak kullandığı stratejilerden değiştirme maliyetleri ve alternatiflerin cazibesi ile müşteri sadakati arasındaki ilişkiler incelenmiştir. Ayrıca araştırmada algılanan hizmet kalitesi ve müşteri sadakati ile ağızdan ağıza pazarlama davranışı arasındaki ilişkiler de araştırılmıştır.

Araştırma sonuçları tüzel müşterilerin ana bankalarından aldıkları hizmet kalitesine yönelik algıları ile bankanın kurumsal imajı, müşterilerin bankaya yönelik güven ve tatmin geliştirmeleri, değiştirme maliyetlerinin algılanması ve alternatiflerin çekiciliği arasında güçlü ilişkiler olduğuna işaret etmektedir. Buna göre araştırmada hizmet kalitesi arttıkça müşterilerin bankanın kurumsal imajına yönelik algılarının da arttığı sonucuna ulaşılmıştır. Alan yazın incelendiğinde Chien ve Chi (2019)'nin araştırma sonuçları algılanan hizmet kalitesi arttıkça kurumsal imajın arttığına işaret ederken, Pechinthorn ve Zin (2020)'in çalışmaları ise algılanan hizmet kalitesinin kurumsal imaj üzerinde bir etkisi olmadığına işaret etmektedir. Araştırmada ana bankanın hizmet kalitesi arttıkça tüzel müşterilerin ana bankaya yönelik tatmin düzeylerinin de yükseldiği sonucuna ulaşıımıştır. Ulaşılan bu sonuç Chien ve Chi (2019), Hasan, Uddin, Alim, Azad ve Ali (2020), Ghouzhdi (2020), Kırcova vd. (2020) ve Srivastava ve Vishnani (2021)'nin ulaştığı sonuçlarla da desteklenirken, Omar vd. (2021)'nin ulaştığı sonuçtan farklılaşmaktadır. Tatminle benzer şekilde algılanan hizmet kalitesi arttıkça tüzel müşterilerin ana bankalarına olan güvenleri de artmaktadır. Boonlertvanich (2019) ve Pooya vd. (2020)'nin araştırma sonuçları da hizmet kalitesi arttıkça, müşterilerin hizmet sağlayıcılarına olan güvenlerinin arttığına işaret etmektedir. Bununla birlikte araştırma sonuçları algılan hizmet kalitesi arttıkça, tüzel müşterilerin ana bankalarını değiştirmeleri durumunda katlanacakları ekonomik, sosyal ve psikolojik maliyetlerin daha yüksek düzeyde algılandığı ve alternatif bankaların tekliflerinin cazip olarak kabul edilmediğine işaret etmektedir. Edward ve Sahadev (2011)'in çalışmaları da ulaşılan bu sonucu desteklemektedir. Araştırma kapsamında algılanan hizmet kalitesinin yanı sıra tüzel müşterilerin tatminini etkileyen diğer bir unsur ise müşterilerin ana bankalarına duyduğu güvendir. Müşterilerin ana bankalarına yönelik güvenleri arttıkça, müşteri tatmini de doğru orantılı olarak artmaktadır. Ulaşılan bu sonuç Eren (2021)'in çalışmasında elde ettiği sonuçla desteklenmektedir. Bununla birlikte araştırmada kurumsal imaj ile müşteri tatmini arasında bir ilişki bulunmamıştır. Hasan vd. (2020)'nin araştırma sonuçları kurumsal imajın müşteri tatmini üzerinde bir etkisi olmadığına işaret ederken, Chien ve Chi (2019) ve Eren (2021)'in çalışmaları ise kurumsal imajın müşteri tatminini önemli ölçüde etkilediğini yansıtmaktadır. Tüzel müşterilerin ana bankalarına yönelik tatmin geliştirmesinde aldığı hizmet ve güven önemli olmakta, ancak bankanın kamuoyunda sahip olduğu imaj müşteri bakış açısında tatmin geliştirmek için yeterli olmamaktadır. Müşterilerin banka ile yaşadığı kendi 
olumlu/olumsuz deneyimlerinin tatmin kararında daha etkili olmasının, sonuca bu şekilde yansıdığı düşünülmektedir.

Araştırma sonuçları tüzel müşterilerin ana bankalarına olan sadakatleri ile bankanın sunduğu hizmetin kalitesi, müşteri tatmini ve alternatiflerin cazibesi arasında pozitif yönde bir ilişki olduğuna işaret etmektedir. Buna göre bankanın sunduğu hizmet kalitesine yönelik olumlu algılar, müşteri sadakatinin gelişimine yardımcı olmakta ve sunulan hizmetin kalitesi arttıkça müşteri sadakati de artmaktadır. Ulaşılan bu sonuç alan yazında Zhou, Lim, Yu, Xu, Ren ve Xu (2021)'nun araştırma sonuçları ile desteklenirken, Hasan vd. (2020) ve Omar vd. (2021)'nin ulaştğı sonuçtan farklılaşmaktadır. Benzer şekilde müşterilerin bankaya yönelik tatmini arttıkça, müşteri sadakati de artmaktadır. Bu sonuç Hasan vd. (2020), Teeroovengadum (2020), Valentika, Nursyirwan ve Ardaninggar (2020) ve Kırcova vd. (2020)'nin araştırma sonuçları ile benzerlik göstermektedir. Araştırma bulgularında gözlemlenen ve müşterilerin rakip bankaların sunduğu tekliflerin çekiciliği ile müşteri sadakati arasındaki ilişkiye bağlı olarak, alternatif bankaların tekliflerinin ne kadar az cazip görünürse, müşteri sadakatinin de o kadar yüksek geliştiği sonucuna ulaşılmıştır. Chuah, Marimuthu, Kandampully ve Bilgihan (2017) ve Ghazali vd. (2016)'in araştırma sonuçları da rakiplerin tekliflerinin cazibesi azaldıkça, müşteri sadakatinin artı̆̆ını yansıtmaktadır. Bu araştırma ayrıca tüzel müşterilerin bankanın kurumsal imajına yönelik algıları ile müşterilerin ana bankalarına yönelik sadakatini arasında bir ilişki olmadığına işaret etmektedir. Benzer şekilde Valentika vd. (2020) çalışmalarında kurumsal imajın sadakat üzerinde herhangi bir etkisi olmadığı sonucuna ulaşırken, Kırcova vd. (2020) ve Islam, Islam, Pitafi, Xiaobei, Rehmani, Irfan ve Mubarak (2021) ise araştırmalarında kurumsal imajın sadakatin belirleyicilerinden biri olduğu sonucuna ulaşmışlardır. Araştırma sonuçları kurumsal imaj ile benzer şekilde müşterilerin ana bankalarına duydukları güven ile müşterilerin bankaya olan sadakatleri arasında herhangi bir ilişki olmadığına işaret etmektedir. Boonlertvanich (2019) ve Islam vd. (2021)'nin araştırmaları ise ulaşılan sonucun aksine güvenin müşteri sadakatini etkilediğine işaret etmektedir. Bu araştırmada ulaşılan bir diğer sonuç ise müşterilerin bankayı değiştirmeleri durumunda katlanmaları gereken değiştirme maliyetleri ile müşteri sadakati arasında herhangi bir ilişkinin olmamasıdır. Ulaşılan bu sonuç Valentika vd. (2019)'nin ulaştığı sonuç ile paralelik göstermektedir. Aydın, Özer ve Arasıl (2005), Ghazali vd. (2016) ve Nguyen vd. (2020) ise araştırmalarında değiştirme maliyetlerinin müşteri sadakati yaratmada önemli bir unsur olduğu sonucuna ulaşmışlardır. Bu bağlamda tüzel müşterilerin ana bankalarına sadakat geliştirmelerinde, bankanın kendilerine sunduğu hizmetin kalitesinin yanı sıra alternatif bankaların cazip teklifleri ve faiz ve komisyon fiyatlandırmalarındaki avantajların, sonucu bu yönde etkilediği düşünülmektedir. Bu noktada müşteriler hizmet kalitesini olumlu algılamadıkça ve tatmine ulaşmadıkça değiştirme maliyetleri, bankanın kamuoyunda sahip olduğu imaj ve bankaya olan güvenleri ne kadar yüksek olursa olsun müşteri sadakati gelişmemektedir. Araştırma sonuçları ayrıca algılanan değiştirme maliyetlerinin sadakati tek basına etkileyen bir unsur olmadığına işaret ederken, algılanan değiştirme maliyetlerinin müşteri tatmini ve sadakati arasındaki ilişkiyi güçlendirdiğini göstermektedir. Algılanan değiştirme maliyetleri ne kadar güçlü algılanırsa, müşteri tatmini ve müşteri sadakati arasındaki ilişki o derece güçlenmektedir. Ulaşılan bu sonuç Kim, Park, Park, Kim ve Kim (2018)'in araştırma bulguları ile desteklenirken, Aydın vd. (2005) ve Ghazali vd. (2016)'nin ulaştı̆̆ı sonuçtan farklılaşmaktadır. Önerilen hipotezin aksine algılanan değiştirme maliyetleri rakip bankaların cazip teklifleri ile sadakat arasındaki ilişkide herhangi bir rol oynamamaktadır. Ghazali vd. (2016) de araştırmalarında aynı sonuca ulaşmışlardır. Bu sonuçlar, tüzel müşterilerin ana bankalarından ayrılmalarını engelleyen ilişkisel ya da maddi maliyetler ne olursa olsun, kendileri için cazip olduğunu düşündükleri bir alternatif olması durumunda ve bu cazip tekliflerin sağlayabileceği avantajların, değiştirme maliyetlerinin yaratacağı dezavantajlardan üstün olması durumunda ana bankalarına yönelik sadakatlerini sorguladıklarını düşündürmektedir.

Araştırma sonuçları müşteri sadakati ile müşterilerin olumlu ağızdan ağıza pazarlama davranışı arasında olumlu bir ilişkinin varlığını yansıtmaktadır. Tüzel müşterilerin ana bankalarına yönelik sadakati arttıkça, çevrelerine ana bankalarını tavsiye etmeleri, hatta çevrelerini bu banka ile çalışmaya teşvik etme düzeyleri de yükselmektedir. Kitapçı vd. (2014), Casidy ve Wymer (2015) ve Mazzarol, Soutar ve Limnios (2019) da araştırmalarında müşteri sadakati arttıkça, ağızdan ağıza pazarlama davranışııın da arttığı sonucuna ulaşmışlardır. Bununla birlikte araştırma sonuçları önerilen hipotezin aksine algılanan hizmet kalitesi ile ağızdan ağıza pazarlama davranışı arasında bir ilişki olmadığına işaret etmektedir. Liu ve Lee (2016) 
ve Mahadin ve Akroush (2019) ise araştımalarında algılanan hizmet kalitesinin ağızdan ağıza pazarlama davranışını olumlu etkilediği sonucuna ulaşmışlardır. Bu sonuç, tüzel müşterilerin ana bankaları hakkında çevrelerine olumlu referans vermelerinde aldığı hizmetin kalitesinden ziyade özellikle fiyatlandırma, cazip teklifler ve somut çıkarları konusunda tatmine ulaştırımalarının daha ön planda tutulduğunu düşündürmektedir. Günümüzde müşterilerin ana bankası olmak ve bu başarıyı sürdürmek bankaların yeni müşteriye ulaşma maliyetlerini azaltmanın yanı sıra, yüksek kar, süreç kolaylıkları ve sadık müşteriler aracılığı ile ücretsiz ve gönüllü tanıtım gibi pek çok avantajı da beraberinde getirmektedir. Bu noktada özellikle tüzel müşterilerin ana bankası olmaya devam etmek önemli bir amaçtır. Araştırmada ulaşılan sonuçlar doğrultusunda bankaların tüzel müşterilerinin ana bankası olarak müşteri tatmini, müşteri sadakati ve olumlu ağızdan ağıza pazarlama davranışı geliştirmelerine yardımcı olmak için aşağıdaki öneriler sunulabilir:

- Tüzel müşteriler, firma temsilcisinden, finans müdürüne ve firma ortağına kadar çoklu hizmet sunumu gerektirdiğinden; her hizmet noktasında yüksek kalitede hizmet sunumu sağlanmalıdır. Bu noktada müşterilerle iletişime geçen banka personelinin davranışından, alternatif dağıtım kanallarına kadar (internet/mobil bankacılık, atm vb.) verilen hizmetin kalitesinde bütünlük sağlanmalıdır. Bunu sağlamak için ise müşterilerin deneyimleri hakkında açık uçlu sorular sorularak beklentileri ve aldıkları performans hakkında bilgi alınmalı ve bu doğrultuda hizmet kalitesi geliştirilmelidir. Çünkü bankanın sunduğu hizmet kalitesi müşterilerin bankaya yönelik güven, tatmin ve sadakat geliştirmesinde en önemli unsurlardan biridir. Ayrıca kurumsal imaj müşterilerin olumlu hizmet algılarından beslendiğinden, müşterilerin olumlu deneyimleri arttıkça bankanın kurumsal imajı da olumlu yönde gelişecektir.

- Bankaların müşterilerinde kendilerine yönelik güven oluşturmadan tatmin müşteri yaratmaları oldukça zordur. Bu nedenle bankalar gerek çalışanları gerekse dijital platformlar aracılığı ile müşteri çıkarlarının her şeyin önünde olduğunu müşterilerine hissettirmesi önemlidir. Özellikle tüzel müşterilerin yüksek hacimli ve profesyonellik gerektiren işlemleri için risk endişelerini azaltması müşteri tatminine giden yolda önemli bir basamaktır. Tüzel müşteriler tatmin olduklarından ana bankalarına sadık olmaları da mümkün olmaktadır.

- Bankalar müşterilerin kendileri ile çalışmaya devam etmelerini sağlamak adına değiştirme maliyetlerini yaratmalı ve bankayı değiştirmeleri durumunda katlanacakları maliyetleri müşterilerine güçlü şekilde hissettirmelidirler. Bu sayede tatmin müşterileri banka ile çalışmaya devam etmesi de güçlendirilebilir.

- Rakipler her zaman tüzel müşterilere kendileri ile çalışmaları için teklifler sunmaktadır. Bu tekliflerin cazibesi arttıkça müşterilerin ana bankalarına yönelik sadakati azalacağından, bankanın ana banka olmaya devam edebilmesi için rakipleri ve onların kendi müşterilerine yönelik ilgilerini, sunduğu teklifleri sürekli takip etmesi gerekmektedir. Kendi hizmet ve fiyatlandırmasına da rekabete yönelik esneklik kazandırması, ana banka olmaya devam etmesi için önemlidir. Bununla birlikte ilişki pazarlamanın doğru yönetilmesi alternatif bankaların cazip tekliflerinin müşteriler üzerindeki olumsuz etkileri zayıflatılabilir.

- Yeni müşteri kazanımı bankalar için hayati önemdedir. Yeni tüzel müşteri kazanımında da ağızdan ağıza pazarlama önemli bir referans unsur olduğundan, bankalar mevcut müşterilerinin çevrelerine kendilerini tavsiye etmeleri sağlamalıdırlar. Bu ise ancak müşteri sadakati ile sağlanabileceğinden öncelikle sadık müşteri yaratmanın önündeki engelleri kaldırmalıdırlar. Çünkü müşteri sadakati ancak yüksek hizmet kalitesi ve tatmin müşteri yaratmakla gerçekleşebilir.

\section{Araştırmanın Kısıtları ve Gelecek Çalışmalara Öneriler}

Çalışmanın birtakım kısıtları mevcuttur. Bunlardan ilki anketin kısıtlı bir süre içinde yapılmış olması ve örneklemin ulaşılabilen katılımcılar ile sınırlı olmasıdır. Ayrıca çalışmada kolayda örnekleme tekniği kullanıldığı için örneklem hedef kitlenin tamamını temsil etmemektedir. Bununla birlikte çalışmanın uygulaması tüzel müşteri örneklemi ile gerçekleştirildiğinden sonuçlar tüzel müşterilere yönelik bulguları yansıtmaktadır. Bu nedenle çalışmada elde edilen sonuçlar genelleştirilmemelidir. 
Gelecekteki çalışmalar tüketicilerin satın aldıkları ana markalara yönelik tutumlarını ortaya koymak amacıyla yapılacağı gibi, farklı sektörlerde, farklı ülke ve kültürlerdeki tüketici gruplarının da davranış ve tutumlarını ortaya koymak amacıyla tasarlanabilir. Bu çalışmada tüzel müşterilerin ana bankalarına yönelik sadakati; hizmet kalitesi, müşteri tatmini, müşteri güveni, kurumsal imaj, algılanan değiştirme maliyetleri ve alternatiflerin cazibesi kapsamında açıklanmaya çalışılmıştır. Sonraki araştırmalarda müşterilerin ana ürün sağlayıcıya olan tekrarlayan satın alma niyeti ve sosyal etki kavramının bu ilişkideki rolü de ayrıca incelenebilir.

\section{Beyan ve Açıklamalar (Declarations and Disclosures)}

Yazarların Etik Sorumlulukları (Ethical Responsibilities of Authors): Bu çalışmanın yazarı, araştırma ve yayın etiği ilkelerine uyduğunu kabul etmektedir.

Etik Kurul Onayı (Ethical Approval): Bu çalışmada kullanılan verilerin toplanması için Ufuk Üniversitesi Sosyal ve Beşeri Bilimler Bilimsel Araştırma ve Yayın Etiği Kurulu'ndan 2020/63 sayı ve 24.09.2020 tarihli etik kurul onayı alınmıştır.

Çıkar Çatışması (Conflicts of Interest): Yazar tarafından herhangi bir çıkar çatışması beyan edilmemiştir.

Finansal Destek (Funding): Yazar, çalışmanın hazırlanması ve/veya yayınlanması sürecinde herhangi bir finansal destek almamıştır.

Yazar Katkı Oranı (Author Contributions): Yazar; kavramlaştırma ve çalışma dizaynı, verilerin toplanması, verilerin analizi ve sonuçların yorumlanması, çalışmanın ilk/taslak halinin yazılması, çalışmanın gözden geçirilmesi ve düzenlenmesi/düzeltilmesi aşamalarından tek başına sorumlu olduğunu beyan etmektedir.

intihal Denetimi (Plagiarism Checking): Bu çalışma, intihal tarama programı kullanılarak intihal taramasından geçirilmiştir.

\section{Kaynaklar}

Andreassen, T. W., \& Lindestad, B. (1998). The effect of corporate image on in the formation of customer loyalty. Journal of Service Research, 1(1), 82-92.

Abratt, R., \& Mofokeng, T. N. (2001). Development and management of corporate image in South Africa. European Journal of Marketing, 35(3/4), 368-386.

Alkhouli, S. (2018). The effect of banks website service quality and e-satisfaction on e-loyalty: An empirical study on Swedish Banks. International Journal of Business and Management, 13(1), 1-12

Aydın, S., \& Özer, G. (2005). The analysis of antecedents of customer loyalty in the Turkish mobile telecommunication market. European Journal of Marketing, 39 (7/8), 910-925.

Aydın, S., Özer, G., \& Arasıl, Ö. (2005). Customer loyalty and the effect of switching costs as a moderator variable. Marketing Intelligence \& Planning, 23(1), 89-103.

Bagozzi, R. P., \& Yi, Y. (1988). On the evaluation of structural equation models. Journal of the Academy of Marketing Science, 16(1), 74-94.

Ball, D., Coelho, P. S., \& Vilares, M. J. (2006). Service personalization and loyalty. Journal of Services Marketing, 20(6), 391-403.

Bankacılık Düzenleme ve Denetleme Kurulu, (2020). Türk Bankacılık Sektörü Temel Göstergerleri, Haziran 2020. https://www.bddk.org.tr/ContentBddk/dokuman/duyuru_0846_01.pdf (Erişim Tarihi: 18 Ekim 2020).

Bansal, H. S., Taylor, S. F., \& James, Y. S. (2005). Migrating' to new service providers: Toward a unifying framework of consumers' switching behaviors. Journal of the Academy of Marketing Science, 33(1), 96-115.

Barich, H., \& Kotler, P. (1991). A framework for marketing image management. Sloan Management Review, 2(2), 94104.

Bayol, M. P., de La Foye, A., Tellier, C., \& Tenenhaus, M. (2001). Use of PLS path modelling to estimate the European Consumer Satisfaction Index (ECSI) model. Statistica Applicata, 12(3), 361-375.

Berry, L. L., \& Parasuraman, A. (1991). Marketing services: Competing through quality. New York: The Free Press.

Bloemer, J., Ruyter, K., \& Wetzels, M. (1998). On the relationship between perceived service quality, service loyalty and switching costs. International Journal of Industry Management, 9(5), 436-53. 
Blut, M., Chowdhry, N., Mittal, V., \& Brock, C. (2015). E-service quality: A meta-analytic review. Journal of Retailing, 91(4), 679-700.

Boonlertvanich, K. (2019). Service quality, satisfaction, trust, and loyalty: The moderating role of main-bank and wealth status. International Journal of Bank Marketing, 37(1), 278-302.

Brakus, J. J., Schmitt, B. H., \& Zarantonello, L. (2009). Brand experience: What is it? How is it measured? Does it affect loyalty? Journal of Marketing, 73(3), 52-68.

Burnham, T. A., Frels, J. K., \& Mahajan, V. (2003). Consumer switching costs: A typology, antecedents, and consequences. Journal of the Academy of Marketing Science, 31(2), 109-126.

Caruana, A. (2002). The effect of service quality and the mediating role of customer satisfaction. European Journal of Marketing, 36(7/8), 811-28.

Casidy, R., \& Wymer, W. (2015). The impact of brand strength on satisfaction, loyalty and WOM: An empirical examination in the higher education sector. Journal of Brand Management, 22(2), 117-135.

Chang, H. H., Wong, K. H., \& Li, S. Y. (2017). Applying push-pull-mooring to investigate channel switching behaviors: Mshopping self-efficacy and switching costs as moderators. Electronic Commerce Research and Applications, 24, 50-67.

Chang, H. H., \& Chen, S. W. (2008). The impact of customer interface quality customer satisfaction and switching costs on e-loyalty: The moderating role of internet experience. Computers in Human Behavior, 24, 2927-2944.

Chen, P. Y., \& Hitt, L. M. (2002). Measuring switching costs and the determinants of customer retention in internet enabled business: A case of on-line brokerages. Information Systems Journal, 13(3), 255-74.

Chen, H., Liu, J. Y., Sheu, T. S., \& Yang, M. (2012). The impact of financial services quality and fairness on customer satisfaction. Managing Service Quality, 22(4), 399-421.

Chien, L. H., \& Chi, S. Y. (2019). Corporate image as a mediatorbetween service quality andcustomer satisfaction: Difference across categorizedexhibitors. Heliyon, 3-24.

Chin, W. W., Marcolin, B. L., \& Newsted, P. R. (1996). A partial least squares latent variable modeling approach for measuring interaction effects: results from a Monte Carlo simulation study and voice mail emotion/adoption study. Information Systems Research, 14(2), 189-227.

Cho, J. E., \& Hu, H. (2009). The effect of service quality on trust and commitment varying across generations. International Journal of Consumer Studies, 33, 468-476.

Chou, P. F., \& Lu, C. S. (2009). Assessing service quality, switching costs and customer loyalty in home-delivery services in Taiwan. Transport Reviews, 29(6), 741-758.

Chuah, S. H.-W., Marimuthu, M., Kandampully, J., \& Bilgihan, A. (2017). What drives Gen Y loyalty? Understanding the mediated moderating rolesof switching costs and alternative attractiveness in the value-satisfaction-loyalty chain. Journal of Retailing and Consumer Services, 36, 124-136.

Clemes, M. D., Shu, X., \& Gan, C. (2014). Mobile communications: A comprehensive hierarchical modeling approach. Asia Pacific Journal of Marketing and Logistics, 26(1), 114-146.

Colgate, M., \& Lang, B. (2001). Switching barriers in consumer markets: An investigation of the financial services industry. Journal of Consumer Marketing, 18 (4), 332-47.

Cooper, R. B., \& Zmud, R. W. (1990). Information technology implementation research: A technological diffusion approach. Management Science, 36 (2),123-139.

Cronin, J. J., \& Taylor, S. A. (1992). Measuring service quality: A reexamination and extension. Journal of Marketing, 56, 55-68.

de Ruyter, K., Wetzels, M., \& Bloemer, J. (1997). On the relationship between perceived service quality, service loyalty and switching costs. International Journal of Service Industry Management, 9 (5), 436-453.

Dick, A. S., \& Basu, K. (1994). Customer loyalty: towards an integrated framework. Journal of The Academy of Marketing Science, 22(2), 99-113.

Doney, P. M., \& Cannon, J. P. (1997). An examination of the nature of the trust in buyer-seller relationship. Journal of Marketing, 61, 35-51.

Edward, M., \& Sahadev, S. (2011). Role of switching costs in the service quality, perceived value, customer satisfaction and customer retention linkage. Asia Pacific Journal of Marketing and Logistics, 23(3), 327-345.

Eren, B. A. (2021). Determinants of customer satisfaction in chatbot use: Evidence from a banking application in Turkey. International Journal of Bank Marketing, Vols ahead-of-print Nos ahead-of-print. 
Fornell, C. (1992). A national customer satisfaction barometer: The Swedish experience. Journal of Marketing, 56, 6-21.

George, D., \& Mallery, P. (2010). SPSS for windows step by step: A simple study guide and reference. Boston, MA: Pearson.

Geebren, A., Jabbar, A., \& Luo, M. (2021). Examining the role of consumer satisfaction within mobile eco-systems: Evidence from mobile banking services. Computers in Human Behavior, 114, 1-12.

Ghali, Z. (2021). Motives of customers' e-loyalty towards e-banking services: a study in Saudi Arabia. Journal of Decision Systems, 1-22.

Ghazali, E., Nguyen, B., Mutum, D. S., \& Mohd-Any, A. S. (2016). Constructing online switching barriers: examining the effects of switching costs and alternative attractiveness on e-store loyalty in online pure-play retailers. Electron Markets, 26, 157-171.

Gray, E. R., \& Balmer, J. M. T. (1998). Managing corporate image and corporate reputation. Long Range Planning, 31(5), 695-702.

Gremler, D. D. (1995). The effect of satisfaction, switching costs, and interpersonal bonds on service loyalty. AZ State University, Unpublished Doctoral Dissertation.

Gremler, D. D., \& Brown, S. W. (1996) Service loyalty: Its nature, importance, and implications. B. Edvardsson, S.W. Brown ve R. Johnston (Yay.Haz.). Advancing service quality: A global perspective, international service quality association içinde (ss.171-180). Jamaica: NY.

Grönroos, C. (1983). Strategic management and marketing in the service sector. Cambridge, MA: Marketing Science Institute.

Hair, J. F., Hult, G. T. M., Ringle, C. M., \& Sarstedt, M. (2014). A primer on partial least squares structural equation modeling (PLS-SEM). CA: SAGE Publications.

Hallowell, R. (1996). The relationships of customer satisfaction, customer loyalty and profitability: an empirical study. International Journal of Service Industry Management, 7(4), 27-42.

Haron, R., Subar, N. A., \& Ibrahim, K. (2020). Service quality of Islamic banks: satisfaction, loyalty and the mediating role of trust. Islamic Economic Studies, 28(1), 3-23.

Hasan, M., Uddin, A., Alim, A., Azad, R., \& Ali, B. (2020). The effects of corporate image, service quality, consumer satisfaction, and perceived value on consumer loyalty: A field experience. International Review of Business Research Papers, 16(1), 160-176.

Helm, S., \& Schlei, J. (1998). Referral potential-potential referrals. An investigation into customers' communication in service markets. Marketing Research and Practice, 41-56.

Hsieh, Y., \& Hiang, S. (2004). A study of the impacts of service quality on relationship quality in search-experiencecredence services. Total Quality Management \& Business Excellence, 15, 43-55.

Hsu, M. H., Ju, T. L., Yen, C. H., \& Chang, C. M. (2007). Knowledge sharing behavior in virtual communities: The relationship between trust, self-efficacy, and outcome expectations. Int. J. Human-Computer Studies, 65, 153169.

Hu, H. H., Kandampully, J., \& Juwaheer, T. D. (2009). Relationships and impacts of service quality, perceived value, customer satisfaction, and image: An empirical study. The Service Industries Journal, 29(2), 111-125.

Ifie, K., Simintiras, A. C., Dwivedi, Y., \& Mavridou, V. (2018). How service quality and outcome confidence drive preoutcome word-of-mouth. Journal of Retailing and Consumer Services, 44, 214-221.

Islam, T., Islam, R., Pitafi, A. H., Xiaobei, L., Rehmani, M., Irfan, M., \& Mubarak, M. S. (2019). The impact of corporate social responsibility on customer loyalty: The mediating role of corporate reputation, customer satisfaction, and trust. Sustain Prod Consum 25, 123-135.

Jackson, B. B. (1985). Winning and keeping industrial customers: The dynamics of customer relationship. Lexington, MA: Lexington Books.

Jones, T. O., \& Sasser, W. E. (1995). Why satisfied customers defect. Harvard Business Review, 73(6), 88-99.

Jones, M. A., Beatty, S. E., \& Mothersbaugh, D. V. (2002). Why customers stay: measuring the underlying dimensions of services switching costs and managing their differential strategic outcomes. Journal of Business Research, 55, 441-50.

Kandampully, J., \& Suhartanto, D. (2000). Customer loyalty in the hotel industry: the role of customer satisfaction and image. International Journal of Contemporary Hospitality Management, 12(6), 346-351. 
Keaveney, S. M. (1995). Customer switching behavior in service industries: An exploratory study. Journal of Marketing, 59 (2), 71-82.

Khoa, B. T. (2020). The impact of the personal data disclosure's tradeoff on the trust and attitude loyalty in mobile banking services. Journal of Promotion Management, 1-24.

Kırcova, İ., Köse, Ş., \& Özer, E. (2020). Şehirde yolculuk: Algilanan hizmet kalitesi, kurum imaji, müşteri memnuniyeti ve müşteri sadakati ilişkisinde şehir hatlari örneği. UiiiD-IJEAS, 28, 79-100.

Kim, Y., Wang, Q., \& Roh, T. (2021). Do information and service quality affect perceived privacy protection, satisfaction, and loyalty? Evidence from a Chinese $\mathrm{O2O}$ - based mobile shopping application. Telematics and Informatics, 56, $1-12$.

Kim, M. K., Park, M. C., Park, J. H., Kim, J., \& Kim, E. (2018). The role of multidimensional switching barriers on the cognitive and affective satisfaction-loyalty link in mobile communication services: Coupling in moderating effects. Computer in Human Behavior, 87, 212-223.

Kitapçı, O., Akdoğan, C., \& Dörtyol, İ. T. (2014). The impact of service quality dimensions on patient satisfaction, repurchase intentions and word-of-mouth communication in the public healthcare industry. Procedia - Social and Behavioral Sciences, 148,161-169.

Klemperer, P. (1995). Markets with consumer switching costs. The Quarterly Journal of Economics, 102(2), 375-94.

Kline, P. (1994). An easy guide to factor analysis. New York: Routledge.

Kline, R. B. (1998). Principles and practice of structural equation modeling. New York: Guilford Press.

KOSGEB, (2018). https://www.kosgeb.gov.tr/

KPMG, (2021). Sektörel Bakış 2020-Bankacılık. https://home.kpmg/tr/tr/home/gorusler/2019/12/sektorel-bakis-2020bankacilik.html (Erişim Tarihi: 01.03.2021)

Kondou, M. (1997). China: Technology policy in a transitional economy - engineering research centers to bridge research units and enterprises. https://www.jstage.jst.go.jp/article/jsrpim/12/3_4/12_KJ00002349955/_pdf/-char/ja (Erişim Tarihi: 20 Ekim 2020).

Lam, R., \& Burton, S. (2006). SME banking loyalty (and disloyalty): a qualitative study in Hong Kong. International Journal of Bank Marketing, 24(1), 37-52.

Lee, J., Lee, J., \& Feick, L. (2001). The impact of switching costs on the customer satisfaction-loyalty link: Mobile phone service in France. Journal of Services Marketing, 15, 35-48.

Lee, Y. K., Ahn, W. K., \& Kim, K. (2008). A study on the moderating role of alternative attractiveness in the relationship between relational benefits and customer loyalty. International Journal of Hospitality \& Tourism Administration, $9(1), 52-70$.

Levesque, T., \& McDougall, G. H. G. (1996). Determinants of customer satisfaction in retail banking. International Journal of Bank Marketing, 14(7), 12-20.

Li, F., Lu, H., Hou, M., Cui, K., \& Darbandi, M. (2021). Customer satisfaction with bank services: The role of cloud services, security, e-learning and service quality. Technology in Society, 64, February, 1-11.

Liu, C.-H. S., \& Lee, T. (2016). Service quality and price perception of service: Influenceon word-of-mouth and revisit intention. Journal of Air Transport Management, 52, 42-54.

Loureiro, S. M. C., Cavallero, L., \& Miranda, F. J. (2018). Fashion brands on retail websites: Customer performance expectancy and e-word-of-mouth. Journal of Retailing and Consumer Services, 41, 131-141.

Lovelock, C., Vandermerwe, S., \& Lewis, B. (1996). Services marketing: A European perspective. NJ.: Prentice-Hall, Englewood Cliffs.

Mahadin, B. K., \& Akroush, M. N. (2019). A study of factors affecting word of mouth (WOM) towards Islamic banking (IB) in Jordan. International Journal of Emerging Market, 14(4), 639-667.

Mazzarol, T., Soutar, G., \& Limnios, E. M. (2019). Member loyalty and WOM in co-operative and mutual enterprises. Journal of Services Marketing, 33/3, 303-315.

McKnight, D. H., Choudhury, V., \& Kacmar, C. (2002). Developing and validating trust measures for e-commerce: An integrative typology. Information Systems Research, 13(3), 334-359.

Moorman, C., Zaltman, G., \& Deshpande, R. (1992). Relationships between providers and users of market research: The dynamics of trust within and between organizations. Journal of Marketing Research, 29(3), 314-328.

Mukerjee, K. (2020). Impact of self-service technologies in retail banking on cross-buying and word-of-mouth. International Journal of Retail \& Distribution Management, 48(5), 485-500. 
Murray, K. B. (1991). A test of services marketing theory: consumer information acquisition activities. Journal of Marketing, 55, 10-25.

Narayandas, N. (1996). The link between customer satisfaction and customer loyalty: An empirical investigation. Working paper, 97-017. Boston, MA.: Harvard Business School.

Nguyen, N., \& LeBlanc, G. (2001). Corporate image and corporate reputation in customers' retention decisions in services. Journal of Retailing and Consumer Services, 8(4), 227-236.

Nguyen, M. H., \& Khoa, B. T. (2019). Customer electronic loyalty towards online business: The role of online trust, perceived mental benefits and hedonic value. Journal of Distribution Science, 17(12), 81-93.

Nguyen, D. T., Pham, V. T., Tran, D. M., \& Pham, D. B. T. (2020). Impact of service quality, customer satisfaction and switching costs on customer loyalty. Journal of Asian Finance, Economics and Business, 7(8), 395-405.

Nyugen, N., Leclerc, A., \& LeBlanc, G. (2013). The mediating role of customer trust on customer loyalty. Journal of Service Science and Management, 6, 96-109.

Odabaşı, Y. (2015). Satışta ve pazarlamada müşteri iiişsileri yönetimi (CRM). İstanbul: Aura Yayıncılık.

Odekerken-Schröder, G., Birgelen, M., Lemmink, J., Ruyter, K., \& Wetzels, M. (2000). Moments of sorrow and joy: An empirical assessment of the complementary value of critical incidents in understanding customer service evaluations. European Journal of Marketing, 34, 107-125.

Omar, S., Mohsen, K., Tsimonis, G., Oozeerally, A., \& Hsu, J.-H. (2021). M-commerce: The nexus between mobile shopping service quality and loyalty. Journal of Retail Consumer Service, 60, 1-15.

O'Leary, S., \& Deegan, J. (2005). Ireland's image as a tourism destination in France: Attribute importance and performance. Journal of Travel Research, 43(3), 247-260.

Oliver, R. (1997). Satisfaction: A behavioral perspective on the consumer. New York: McGraw-Hill.

Oliver, R. L., \& Swan, J. E. (1989). Consumer perceptions of interpersonal equity and satisfaction in transactions: A field survey approach. Journal of Marketing, 53(April), 21-35.

Parasuraman, A., Zeithaml, V. A., \& Berry, L. L. (1988). SERVQUAL: A multiple-item scale for measuring consumer perceptions of service quality. Journal of Retailing, 64(1), 12-40.

Parasuraman, A., Zeithaml, V. A., \& Berry, L. L. (1994). Reassessment of expectations as a comparison standard in measuring service quality: Implications for further research. The Journal of Marketing, 58(1), 111-124.

Patterson, P. G., \& Smith, T. (2003). A cross-cultural study of switching barriers and propensity to stay with service providers. Journal of Retailing, 79(2), 107-120.

Pechinthorn, K., \& Zin, K. Y. S. (2020). The influences of service quality dimensions, corporate image and customer satisfaction on customer loyalty towards a commercial bank in Myanmar. International Journal of Contemporary Research and Review, 11(11), 1-16.

Ping, R. A. (1993). The effects of satisfaction and structural constraints on retailer exiting, voice, loyalty, opportunism, and neglect. Journal of Retailing, 69(Fall), 320-352.

Pooya, A., Khorasani, M. A., \& Ghouzhdi, S. G. (2020). Investigating the effect of perceived quality of self-service banking on customer satisfaction. International Journal of Islamic and Middle Eastern Finance and Management, 13(2), $263-280$

Powpaka, S. (1996). The role of outcome quality as a determinant of overall service quality in different categories of service industries: An empirical investigation. Journal of Services Marketing, 10(2), 5-25.

Purwanto, E., Deviny, J., \& Mutahar, A. M. (2020). The mediating role of trust in the relationship between corporate image, security, word of mouth and loyalty in MBanking using among the millennial generation in Indonesia. Challenges for the Knowledge Society, 15(2), 255-274.

Rajaobelina, L., Prom Tep, S., Arcand, M., \& Ricard, L. (2021). The relationship of brand attachment and mobile banking service quality with positive word-of-mouth. Journal of Product \& Brand Management, Vol. ahead-of-print No. ahead-of-print.

Ranaweera, C., \& Prabhu, J. (2003). The influence of satisfaction, trust and switching barriers on customer retention in a continuous purchasing setting. International Journal of Service Industry Management, 14(4), 374-95.

Raza, S. A., Umer, A., Qureshi, M. A., \& Dahri, A. S. (2020). Internet banking service quality, e-customer satisfaction and loyalty: the modified e-SERVQUAL model. The TQM Journal, 32(6), 1443-1466

Richard, J. E., \& Zhang, A. (2012). Corporate image, loyalty, and commitment in the consumer travel industry. Journal of Marketing Management, 28(5-6), 568-593. 
Rusbult, C.E. (1980). Commitment and satisfaction in romantic associations: A test of the investment model. Journal of Experimental Social Psychology, 16(2), 172-86.

Rotter, J. B. (1967). A new scale for the measurement of interpersonal trust. Journal of Personality, 35(4), $651-665$.

Solunoğlu, A. (2020). Perceived food quality, satisfaction, brand image in restaurants and recommendation intention relation. Journal of Yasar University, 15(60), 833-849.

Srinivasan, S., Anderson, R., \& Ponnau, K. (2002). Customer loyalty in e-commerce: An exploration of its antecedents and consequences. Journal of Retailing, 78(1), 41-50.

Srivastava, S., \& Vishnani, S. (2021). Determinants of mobile bank usage among the bank users in North India. Journal of Financial Services Marketing, 26, 34-51.

Suariedewi, I. G. A. A. M., \& Suprapti, N. W. S. (2020). Effect of mobile service quality to e-trust to develop esatisfaction and e-loyalty mobile banking services. International Research Journal of Management, IT \& Social Sciences, 7(1), 185-196

Tabachnick, B. G., \& Fidell, L. S. (2013). Using multivariate statistics. Boston: Pearson/Allyn \& Bacon.

Teeroovengadum, V. (2020). Service quality dimensions as predictors of customer satisfaction and loyalty in the banking industry: moderating effects of gender. European Business Review, Vol. ahead-of-print No. ahead-of-print

Trabelsi-Zoghlami, A., Berraies, S., \& Yahia, K. B. (2020). Service quality in a mobile-banking-applications context: Do users' age and gender matter? Total Quality Management \& Business Excellence, 31(15-16), 1639-1668.

Türkiye Bankalar Birliği (2020). 21.11.2020 itibarıyla gruplar bazında, banka ve banka şubelerinin sayısı. https://www.tbb.org.tr/modules/banka-bilgileri/banka_sube_bilgileri.asp (Erişim Tarihi: 21 Kasım 2020).

Vandamme, R., \& Leunis, J. (1993). Development of a multi-item scale for measuring hospital service quality. International Journal of Service Industry Management, 4(3), 30-49.

Valentika, N., Nursyirwan, W. I., \& Ardaninggar, S. S. (2020). Switching-costs, corporate image, product quality, and satisfaction level effect on customer loyalty: E- commerce shopee. INCEESS 2020, 17-18 Temmuz 2020, Bekasi, Indonesia.

Walker, J. (1995). Service encounter satisfaction: Conceptualised. Journal of Services Marketing, 9(1), 5-14.

Wang, C. Y. (2010). Service quality, perceived value, corporate image, and customer loyalty in the context of varying levels of switching costs. Psychology \& Marketing, 27(3), 252-262.

Wannenburg, E., Drotsky, T., \& de Jager, J. (2009). Gamers' perceptions of the service quality in the gaming areas of selected casinos in South Africa. African Journal of Business Management, 3(7), 317-324.

Wati, N. W., Kusuma, I. G. A. E. T., \& Widnyana, I. W. (2020). Effect of service quality and corporate image on customer delight and loyalty customer in BPD Bali, Gajah Mada Main Branch, Denpasar Bali. International Journal of Contemporary Research and Review, 11(11), 21914-21926.

Wong, I. A., \& Fong, V. H. I. (2010). Examining casino service quality in the Asian Las Vegas: An alternative approach. Journal of Hospitality Marketing \& Management, 19 (8), 842-865.

$\mathrm{Wu}, \mathrm{L}$. V. (2011). Satisfaction, inertia, and customer loyalty in the varying levels of the zone of tolerance and alternative attractiveness. Journal of Services Marketing, 25(5), 310-322.

$\mathrm{Wu}, \mathrm{H}$. C. (2014). The effects of customer satisfaction, perceived value, corporate image and service quality on behavioral intentions in gaming establishments. Asia Pacific Journal of Marketing and Logistics, 26(4), 540-565.

Wu, J. H. C., Lin, Y. C., \& Hsu, F. S. (2011). An empirical analysis of synthesizing the effects of service quality, perceived value, corporate image and customer satisfaction on behavioral intentions in the transport industry: A case of Taiwan high-speed rail. Innovative Marketing, 7(3), 83-100.

Yang, Z., \& Peterson, R. T. (2004). Customer perceived value, satisfaction, and loyalty: The role of switching costs. Psychology \& Marketing, 21, 799-822.

Yap, B. W., Ramayah, T., \& Shahidan, W. N. W. (2012). Satisfaction and trust on customer loyalty: A PLS approach. Business Strategy Series, 13(4), 154-167

Yi, Y., \& Gong, T. (2013). Customer value co-creation behavior: Scale development and validation. Journal of Business Research, 66(9), 1279-1284.

Zakiy, M., \& Haryanto, M. (2020). Linking of service quality and switching costs with turnover intentions: The mediating role of customer loyalty. Advances in Engineering Research, 201, 1-9.

Zeithaml, V. A. (1988). Consumer perceptions of price, quality, and value: A means-end model and synthesis of evidence. Journal of Marketing, 52(3), 2-22. 
Zeitham, V. A., Bitner, M. J., \& Gremler, D. D. (2009). Services marketing. Singapore: McGraw-Hill Education.

Zhou, Q., Lim, F. J., Yu, H., Xu, G., Ren, X., \& Xu, H. (2021). A study on factors affecting service quality and loyalty intention in mobile banking. Journal of Retailing and Consumer Services, 60, 1-8. 